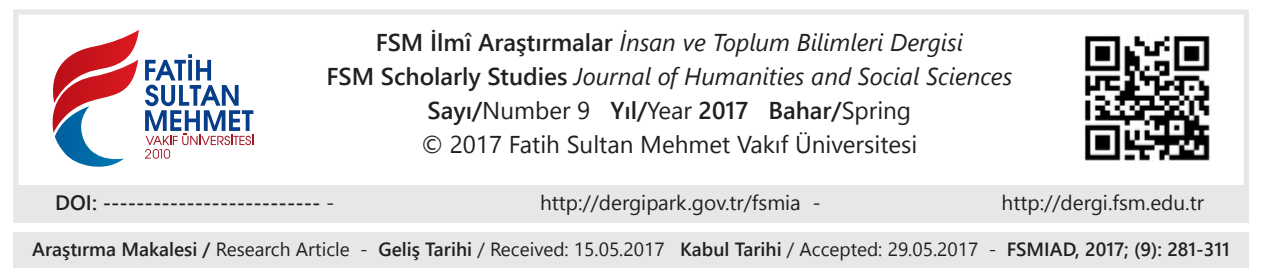

\title{
Hac ve İktidar: Haremeyn'de Erken Dönem Osmanlı İmar Faaliyetleri
}

\author{
$\ddot{O} \mathbf{z}$ \\ Zekeriya Kurşun*
}

Müslümanların iki kutsal kentini (Haremeyn) içine alan Hicaz bölgesi 1517 yllında Osmanlı topraklarına katılmıştır. Ancak Osmanlı sultanları bu tarihten önce de Haremeyn'e yakın ilgi göstermişlerdir. Erken dönemde başlayan bu ilgileri, her yıl Haremeyn ahalisine yardımlar göndermek tarzında gelişmiştir. Sultan I. Selim'den sonra ise durum değişecek ve Osmanlı Sultanları Hicaz bölgesinin bütün sorumluluğunu üstleneceklerdir. Hac ibadetinin sağlıklı yerine getirilmesi için, yol güzergâhlarının bakım ve onar1m1, güvenliğin sağlanması Sultanların temel vazifeleri arasına girecektir. Ancak Osmanlı Sultanları bölgenin imar ve gelişmesi için de özel olarak ilgilenmişlerdir. Başka bir ifade ile bölgeyi imar ederek, yatırım yaparak kendi güç ve iktidarları ile hilafet prestijlerini sürekli kılmışlardır. Bu makalede Osmanlı Devleti'nin erken dönemde (16. yüzyıl) Haremeyn'de hayata geçirdiği imar faaliyetleri ve bu konuda Sultanların gösterdikleri hassasiyetler ele alınmaktadır.

Anahtar Kelimeler: Haremeyn, Mekke, Medine, Osmanlı sultanları.

\section{Pilgrimage and Power: Reconstraction Activities of the Two Sacred Cities of Macca and Medinah under the The Early Ottoman Rule}

\begin{abstract}
The Hedjaz region comprising the two sacred cities for the Muslims was annexed to the Ottoman territories in 1517. However, even before that date, the Ottomans paid attention to Hedjaz region. With such interest emerged in an early period, the Ottomans sent aid and presents to the people of Hedjaz in many occassions. After Sultan Selim I, this interest changed its scope and the Ottoman sultans took the responsibility of the whole Hedjaz region. In order to provide good conditions to the pilgrims to Mecca, the Sultans repaired and maintained the roads, ensured security as their primary responsibilities. The Sultans also personally interested in these processes and they invested in these regions with an attemp to perpetuate their power and prestige. This study attempts to examine the reconstruction works accomplished by the Ottomans in Hejaz in the early period (16th century) and analyze the sensibility of the Ottoman sultans shown towards the region.
\end{abstract}

Keywords: Haremeyn, Mecca, Madinah, Ottoman sultans.

* Prof. Dr., Fatih Sultan Mehmet Vakıf Üniversitesi Edebiyat Fakültesi Tarih Bölümü, İstanbul/ Türkiye, zkursun@fsm.edu.tr 


\section{1- Osmanlı Sultanları ve Haremeyn}

Tarihteki diğer bütün Müslüman devletler gibi Osmanlılar da kuruluşlarından itibaren Haremeyn'e (Müslümanların iki kutsal kenti olan Mekke ve Medine) ilgi göstermiş̧lerdir. Elbette kuruluş yıllarında bu ilgi sadece duygu düzeyinde kalmış, ancak devlet büyüyüp, genişledikçe daha belirgin bir hale gelmiştir. Nitekim Haremeyn ahalisini mutlu etme anlamına gelen sürre gönderme geleneğinin daha Sultan I. Bayezid döneminde (1389-1402) başlayıp Sultan Çelebi Mehmet’ten (1403-1421) itibaren kurumsallaşmaya başladığını tarihi kaynaklar yazmaktadır. Aynı şekilde Sultan II. Murad'ın tahta geçtiği 1421 yılında ataları gibi Medine ve Mekke'ye hazineden bir tahsisat ayırdığı, ayrıca Haremeyn için de Ankara'ya bağlı Balık Hisarı bölgesindeki köylerin gelirlerini tahsis ettiği bilinmektedir' Nitekim şimdilik bilinen en eski Osmanlı Haremeyn vakfının bu olduğu kabul edilmektedir. Sultan II. Murad 1446 yılında yazdırdığı vasiyetinde, "Saruhan ili Manisa'daki" vakfindan Haremeyn'in ahalisine yedi bin flori tahsis edilmesini, ayrıca üç bin florinin de Kâbe'de ve Mescid-i Nebevî'de yapılacak hatimler ve bu sırada okunacak dua ve zikirlere harcanmasını istemiştir².

Osmanlı Sultanları, Balkanlarda ve diğer bölgelerde yaptığı fetihlerin ve elde ettiği zaferlerin haberlerini Hicaz emirlerine göndererek onlar ile paylaşıyorlardı. Fatih Sultan Mehmet 1453 yllında İstanbul'u fethetmesi akabinde Mekke emirine bir fetihnâme yazmış ayrıca bazı hediyeler ile birlikte Haremeyn fukarasına dağıtılması için 2000 flori altın göndermişti ${ }^{3}$. Bu rakam o günkü şartlar için önemli bir meblağ idi ve sıkıntılı bir dönemden geçen bölgenin iktisadi hayatına da bir canlılık getirdiği muhakkaktı. Fatih Sultan Mehmet'ten sonra tahta geçen II. Bayezid zamanında da Haremeyn'i ekonomik olarak destekleme siyaseti takip edilmiş ve her yıl gönderilen sürre miktarı arttırılmıştır.

On altıncı yüzyılın başında genel olarak İslam aleminin özel olarak da Haremeyn'in Portekiz tehdidi ile karşı karşıya kalması Osmanlı Devleti'nin bölgeye daha yakından ilgilenmesini zorunlu kılmıştır. Artık sadece zaman zaman gönderilen hediyeler ile yetinilmeyip, bu tehdidin önüne çıkılması ve durdurulması gerekiyordu. $\mathrm{Bu}$ tehditler karşısında bölgenin uzun zamandan beri hakimi olan

1 Âşık Paşazâde, Osmanoğulları Tarihi, Tevârih-i Âl-i Osman, (Hazırlayanlar: Kemal Yavuz-M.A.Yekta Saraç) İstanbul 2010 (2. Bask1), s. 252.

2 A.g.e., s. 482; İsmail Hakkı Uzunçarş111, "Sultan İkinci Murad'ın Vasiyetnâmesi” Vakıflar Dergisi VI, 1958 s. 4; (Bu belgeyi hatırlatan Yard. Doç. Dr. Fatma Kaytaz'a teşekkür ederim).Bu vasiyetnamenin Türkçe neşri için bak: Midhat Sertoğlu, "II. Murad'ın Vasiyetnamesi” Vakıflar Dergisi, Ankara 1961 VIII, 67 vd); Muhammed el Emin Mekki, Hulefâ-i İzâm-i Osmaniyye Hazretlerinin Haremeyn-i Şerifeyn'deki Asâr-i Mebrûre ve Meşkûre-i Hümayûnları, Dersaadet 1318, s. 19; İsmail, Hakkı Uzunçarş11, Mekke-i Mükerreme Emirleri, Ankara 1984, s. 13; Tuğba Aydeniz, Osmanlı Devleti'nde Mekke'nin Yönetimi (1517-1617), (Marmara Üniversitesi, Türkiyat Araştırmaları Enstitüsü yayınlanmamış doktora tezi), İstanbul 2010, s. 2.

3 Feridun Ahmed Bey, Münşeâtü 's-Selâtîn, İstanbul 1264-1274 (1848-1858), I, 239-240. 
Memlük sultanlarının da Osmanlı Devletinden yardım talep etmeleri Portekiz tehdidinin büyüklüğünü göstermekteydi. Hemen hemen bütün tarihçiler, Osmanlıların, gelişen yeni bölgesel dengeler ve Portekiz tehdidinden dolayı İran, Suriye ve Misır'a yönelmelerine sebep olduğunda müttefiktirler.

Sultan I. Selim 1517 yılında Misır'1 Osmanlı topraklarına kattıktan sonra Mekke ve Medine'yi (Haremeyn) içine alan Hicaz bölgesi de "sulhen" ve "teyemmünen" Osmanlı idaresine girmiştir. Mekke Şerifi II. Berekat, oğlu Ebu Numey ile bir heyeti Kahire'de bulunan Sultan'a göndererek, Osmanlı Devletine bağlılı̆̆ını bildirmesiyle ${ }^{4}$ Hicaz bölgesi de bir Osmanlı idari birimi olacaktır. Bundan sonra Osmanlı Devleti Haremeyn ile sadece Müslümanların kıblegâhı olduğu için ilgilenmeyecek; bilakis kendi idaresindeki bir yerin sorumlusu olarak davranacaktır. Mekke Şerifi'nin Yavuz Sultan Selim henüz Mısır'da iken hızlı bir şekilde tabiiyetini bildirmesi Haremeyn'in iktisadi kalkınmasına da önemli katkı sağlamıştır. Zira bu bağl1lık, hem gücünün zirvesinde olan bir devletin imkânlarının Haremeyn'e akmasını hem de oluşan yol güvenliği sayesinde hac kafilelerinin kesintiye uğramamasını sağlanmıştır.

Osmanlı Sultanı I. Selim, Hicaz'ın Osmanlı idaresine girmesinin hemen ardından, eskiden var olan vakıflara ilave olarak yenilerini de kurup Mısır'daki bazı gelirleri tahsis etmiştir. Örneğin sadece Kâbe'nin kisvesi (örtüsü) için Mısır'daki dokuz köyün gelirleri vakfedilmişti ${ }^{5}$. Kendisinden öncekiler gibi bu vakıfflar ile Haremeyn'e hizmet etmeye başlayan Sultan I. Selim, aynı zamanda Hadimü'l Haremeyni'ş-Şerifeyn ünvanını kullanan ilk Osmanlı padişahı olacaktır'. Nitekim Yavuz Sultan Selim'den itibaren Haremeyn'e hizmet, buranın imarı ile ilgilenmek, hac işlerini düzenlemek sultanlığın mutlak görevleri arasına girecektir.

Haremeyn'in Osmanlı idaresine girmesinden sonra gerek Osmanlı idaresinin genel tabiatı ve gerekse Hz. Peygamber soyundan gelen emirlere duyulan sayg1dan dolayı Mekke emirlerinin eski statüleri aynen korundu. Yavuz Sultan Selim, Hicaz'dan Kahire'ye gelen biat heyetini, Muslihiddin Beyi de Hac emiri tayin ederek geri gönderdi. Heyet ile birlikte Haremeyn ahalisine de hediye olarak 200 bin dinar altın gönderen Sultan, atalarının yolundan gitti. Nitekim eldeki kayıtlara göre, o yıl Haremeyn'de 12 bin kişiye nakit para dağıtıld1 ${ }^{7}$. Sayı değişse de

4 İbn İyas, Bedâyi 'u'z-Zuhûr fî̀ Vekayi 'i'd-Duhûr, (Yavuz'un Misır'1 Fethi ve Misır'da Osmanlı İdaresi, Çeviren: Ramazan Şeşen) İstanbul 2016, s. 179-180: Celâlzade Mustafa, Selim-Nâme (Hazırlayanlar: Ahmet Uğur-Mustafa Çuhadar), Ankara 1990, s. 435-36.; Feridun M. Emecen, "Hicaz'da Osmanlı Hâkimiyetinin Tesisi ve Ebu Numey", Tarih Enstitüsü Dergisi (TED), say1 14 (1994) s. 87-120.

5 Mekki, a.g.e, s. 22-23.

6 Kudbeddin Nehrevalî, el I'lâm bi A'lâmi Beytullahi'l-Harem, Göttingen 1858, II, 278; Hulusi Yavuz, "Osmanlı Padişahlarının İftihar Ettikleri Unvanlardan Biri: Hadimü’l-Haremeyn”, $M a$ kalat,1992/2, s. 8.

7 Uzunçarş11, a.g.e. s. 14. 
her y1l tekrarlanmaya başlanan bu durumun Haremeyn'in iktisadi hayatına bir canlılık kazandırdığı muhakkaktır. Hac için Hicaz'a giden ziyaretçiler ekonomik bir hareketlilik sağlıyordu. Fakat gidenlerin bir bölümünün de muhtaç olmaları ve ayrıca Haremeyn'de ziraî bazı ürünler dışında hiçbir üretimin olmadığı dikkate alındığında bu ekonomik faaliyetin tek başına yeterli olmayacağı aşikârdır. Kendi kaynakları ile geçinmesi ve kalkınması mümkün olmayan bu coğrafyaya, her sene hac mevsiminde çeşitli isimler altında gönderilen nakdî ve aynî yardımların hac ibadetinin yerine getirilmesine katkı verdiği gibi bölgenin imarına da katkı sağladığında kuşku yoktur ${ }^{8}$. Dolayısıyla, ahaliye dağıtılan nakdî ve aynî yardımların bölgenin imar ve kalkınmasında can suyu işlevi gördüğünü ileri sürmek mümkündür. Osmanlı Sultanları Haremeyn'in himayesini üstlenip merkezi bütçeden ve kurdukları vakıflardan destekleyerek bir taraftan İslam'ın bir farizası olan haccın ifasına katkı verirken, diğer taraftan da Müslümanların nezdindeki iktidar ve hilafet gücünü pekiştirmiş oluyorlardı.

\section{2- Haremeyn'de Osmanlı İdari Yapılanması}

Bu yazıda 16. yüzyılda Osmanlıların Haremeyn'deki imar faaliyetleri ele al1nacaktır ${ }^{9}$ fakat konunun daha iyi anlaşılması için yapılan bazı idari düzenlemelerin de kısaca anlatılmasında yarar görülmüştür.

Osmanlı Devleti'nin bölgedeki varlığının hemen başında Haremeyn'in idaresi Mekke emirlerine havale edilmiştir. Hicaz'in geleneksel idaresi ve hac iba-

8 Daha geniş bilgi için bak: Abdülkadir Özcan, Hac (Osmanlılar Dönemi), TDVİA, İstanbul 1996, XIV, 401-405.

9 Haremeyn konusunda farklı dillerde pek çok araştırmalar yapılmıştır. Değişik tarihi dönemler incelenmiş ve birçok bilgiler üretilmiştir. Fakat özellikle Osmanlı dönemi ile ilgili hâlâ pek çok konu tam olarak incelenmemiştir. Özellikle Kanuniden itibaren arşiv belgesinin çokluğuna rağmen bu alanda çalışanların azlığı veya Osmanlıca bilinmemesi Haremeyn çalışmalarını yetersiz kılmaktadır. Türkçe'de Osmanlı öncesine ait Mustafa Sabri Küçükaşçı'nin Abbasilerden Osmanlılara Mekke-Medine Tarihi (İstanbul 2007) başlıklı çalışması bizim araştırma alanımızın hemen öncesine dair önemli bilgiler vermektedir. Bu makalenin konusuna en uygun çalışma ise Suraiya Faroqhi'nin İngilizce'den Türkçe'ye tercüme edilen Hacılar ve Sultanlar, Osmanlı Döneminde Hac 1517-1638 (İstanbul 1995) isimli çalışmasıdır ki bu eserden genişçe istifade edilmiştir. Esasında bu çalışma haccı ve hacıları anlatırken kullandığı birinci elden kaynaklar ile Haremeyn'deki imar faaliyetlerine de kısmen yer vermektedir. Bir diğer çalışma ise Medine'yi konu almaktadır. Osmanlı arşiv belgelerine istinaden önemli istatistiki bilgiler sunan çalışmada Medine'deki Osmanlı imar faaliyetleri ile sosyal ve iktisadi yapı incelenmiştir: An'am Mohammed Osman Elkabashi, Osmanlı Medine'si: XVI. YY'da Mukaddes Bir Şehrin İdarî, Sosyal ve Ekonomik Yapısı, İstanbul Üniversitesi yayımlanmamış doktora tezi, 2006. Medine'de Osmanlı dönemine ait imar faliyetlerinin maddi kalıntılarını ela alan bir başka Türkçe çalışma ise Erciyes Üniversitesinde yapılan bir Yüksek Lisans tezidir. (Sabit Aydın, Osmanlı Döneminde Medine'de Yapılan Tarihi Eserler, Erciyes Üniversitesi, Sosyal Bilimler Enstitüsü, yayımlanmamış Yüksek Lisans Tezi, 2007) Bu çalışma bugün çoğu ayakta olan ve esasında daha geç dönemlerde inşa edilen mekanların bir envanteri niteliğindedir. 
detinin sağlıklı yapılmasına dair birçok meselede Mekke emirleri sorumlu tutulmuştur ${ }^{10}$. Fakat Kızıldeniz kenarındaki Cidde sancak merkezi yapılarak merkezin de bölgede doğrudan kontrolü sağlandı. Zaman içinde Mekke emirlerin görevleri daha ziyade urbanın (bedevi Arapların) işlerini takip ile hac kervanlarının ve yollarının güvenliğini sağlamada Mısır beylerbeyine, Cidde paşasına ve emirülhacca yardımcı olmakla sınırlandırılmıştır. Kolay ulaşımı ve buradan ekonomik destek sağlama imkânları yüzünden Haremeyn'in idaresi uzun süre Mısır üzerinden yapılacaktır. Mısır beylerbeylerine gönderilen emirlerin pek çoğunda, Haremeyn'in ve hac işlerinin ihmal edilmemesi ve gerekli ekonomik desteğin sağlanması 1srarla istenmiş ve adeta kendilerinden beklenen en önemli görevin bu olduğu hatırlatılmıştır ${ }^{11}$.

Haremeyn'i muhafaza etmek, hac kafilelerinin buraya kolayca ve güvenlik içinde ulaştırmayı devlet kendine aslî bir vazife olarak benimsedi. Bu vazife Haremeyn'e civar beylerbeyleri aracılığı ile özellikle de Mısır ve Şam valileri eliyle her yıl özenle yerine getiriliyordu. Hicaz'ın idarî ve malî işleri genellikle Osman11 Misır valileri tarafından yürütülmekteydi. Bununla birlikte Mekke ve Medine kadıları ile nazır-i emval ve şeyhulharemler merkezden tayin ediliyordu. Bu şekilde bölgede çifte kontrol sistemi kuruldu. Daha sonraki dönemlerde ihtiyaca binaen Hicaz idaresi, Mısır'dan ayrılarak Cidde Sancak Beyi eliyle yürütüldü ${ }^{12}$. Hac zamanında hacıların ihtiyaçlarını karşılamak ve güvenliği sağlamakla yükümlü olan beylerbeyi/valiler, maiyetleri ile birlikte bölgenin gelişmesi ve imarı için de çalışmakla yükümlü idiler.

Memlukler zamanında Haremeyn'de mevcut olan geleneksel mansıp ve görevler, Osmanlılar zamanında da aynen kalmıştı. Ancak buna ilave olarak Osman11 Devleti bölgede yeni bir devlet teşkilatlanması yaparak, imar ve gelişmenin alt yapısını kurdu. Buna göre, Hicazdaki Mekke, Medine kadıları; şeyhulharemler, Kâbe miftahdarları gibi geleneksel görevlilerin dışında, valilerin maiyetinde 200 kadar Cidde askeri ve başka görevliler yer almıştı. Ancak daha başından itibaren Osmanlı sultanları bu idari yapılanmada çok dikkatli davranılmasını ve Haremeyn ahalisinin incinmemesini istiyorlardı. Kaynaklarda bunu açıklayan güzel

10 Mekke Emiri Şerif Hasan'a yazılan Mart 1560 tarihli bir hükümde açık bir şekilde görev s1nırları çizilmektedir. Buna göre emire havale edilen asıl görevin hac işlerinin düzenlenmesi ve gelen ziyaretçilerin mekan ve makama uygun bir şekilde ibadetlerini ifầ etmelerinin sağlanması beyan edilmektedir. Başbakanlık Osmanlı Arşivi (BOA), MD, 12/905. (Birinci rakam defter numarasını, ikinci rakam hüküm numarasını göstermektedir. Bundan sonra da böyle verilecektir. Söz konusu hükümlerin tarihleri metin içinde zikredildiğinden dipnotlarda ayrıca gösterilmemiştir.)

11 Bu tür ifadeler en eski Osmanlı kayıtlarından itibaren pek çok kere tekrarlanmaktadır: BOA, $M D, 12 / 868,869,906 ; 28 / 180 ; 33 / 492$.

12 Daha geniş bilgi ve 17. yüzyılda Hicaz idaresinin aldığ 1 şekil için bak: Zekeriya Kurşun, "Hicaz (Osmanlı Dönemi)", Türkiye Diyanet Vakfi İslam Ansiklopedisi, (TDVIA), 1998, 17/439. 
bir örnek zikredilmektedir. Arap topraklarının fethinden sonra Mekke ve Medine'ye Anadolu'dan kadı gönderilip gönderilemeyeceği gündeme gelince, Kazasker Piri Paşa konuyu Yavuz Sultan Selim'den bir tezkire ile sordu. Sultan Selim cevabında Hicaz'ın Osmanlı idaresine katılmasının devlete adeta bir lütuf olduğu ve oradaki uygulamalarda peygamber torunlarının incitilmemesi ve işlerine müdahale edilmemesi gerektiğini beyan etmesi manidardır ${ }^{13}$.

$\mathrm{Bu}$ ifadeler, Osmanlı Sultanlarının daha sonraki yaklaşımlarını ve Mekke emirleri ile olan ilişki biçimini de şekillendirmiştir. Mekke'nin hemen yanı başında kurulan Cidde sancağı ile emirlerin idaresinin de kontrol edilmesi bu uyarının bir ihlali olarak görülmedi. Zira devlet idaresi sadece gelenekler ile yürütülemezdi. Hac yolu güvenliği ve hac işleri ise ihmale gelmeyecek derecede önemli idi. Bunun da sadece Mekke emirleri ile yapılmasına imkân yoktu. Bir nevi uzaktan kontrol mekanizması kuruldu. Özellikle hac ile ilgili görevlerinde ihmal veya eksiklik meydana geldiğinde emirler uyarılmakta ve derhal müdahaleler yapılmaktayd1. Zira her yıl Mekke emirlerine gönderilen nâme-i hümâyunlarda özellikle vurgulanan husus hacıların ve Haremeyn ahalisinin işlerinin adalete uygun takip edilmesiydi. Emniyetin sağlanması, iaşenin temini ve pahalılığın önlenmesi ile Haremeyn'in imarına önem verilmesi de emirlerden ssrarla talep edilmekteydi. $\mathrm{Bu}$ hizmetlerin yapılması için gerekli maddi yardımları göndermeleri için diğer devlet görevlileri de sürekli uyarılıyordu. Ayrıca bu emirlerin yerine getirilip getirilmediği de sıkı sıkıya takip ediliyordu.

Medine ahalisinin ve mücavir olarak orada yaşayanların işlerinin adil bir şekilde takip edilmesi ve özellikle bölgeye gönderilen sadaka ve diğer tahsisatın doğru dağıtılması için İstanbul sürekli Mısır veya Cidde'yi uyarıyordu. Mesela, 1566 yılında Mısır beylerbeyine gönderilen bir fermanda Mescid-i Nebevînin hemen yanında bir deponun ve bir kulenin inşa edilerek gönderilen aynî sadakaların burada saklanması emredilmiştir. Ayrıca bunun muhafazası için de bir ağanın nezaretinde elli kişinin istihdamı istenmiştir ${ }^{14}$. Bu derece yüksek bir muhafaza birliğinin oluşturulması, Medine'ye yıl boyu gönderilen sadaka ve zahirenin ne

13 Yavuz Sultan Selim'in Kazasker Piri Paşa'ya cevabı: "Yeryüzünde Muhammed'in dini ortaya çıkalı dokuz yüz yıldan fazla olmuştur. Mekke-i Muazzama Harem-i İlahi; Medine-i Münevvere ise Hazreti Peygamberin tahtgâhıdır. Bu zamana kadar dışarıdan onlara kadı gönderilmiş midir? Mekke ve Medine padışahlığı kainatın efendisinin şerefli çocuklarının ellerindedir. Ben o memleketleri asker ile varıp almadım. Onlar tam bağlılık, güzel edep ve lütuflarından bana itaat, iyilik ve olgunlukla bağlanıp saygı gösterdiler. Bu şerefin mükafatı bana gerektir. Gece gündüz yüce Allah'a şükür ve senalar ederim ki, Hak teâlanın lütuf ve ihsanlarındandır ki, Mekke ve Medine'de bayram ve Cuma günleri hutbelerde adım anılmaktadır. Bu mutluluğu bütün dünya padişahlığına vermem. Haremeyn-i Şerifeyn halkına ne çeşit gayret, iyilik, şefkat ve gözetme mümkün ise esirgeme. Fakat sakın ha sakın, Mekke ve Medine işlerine müdahale etme." Celâlzade Mustafa, Selim-Nâme, s. 44-45, 268. (Metnin sadeleştirmesi kitabı hazırlayanlara aittir)

14 BOA, MD 5/1084. 
denli çok olduğunu işaretidir. Bu da gösteriyor ki Mısır'ın Osmanlı idaresine alınmasından sonra yaklaşık elli yıl içinde Haremeyn'e lojistik destek sağlama işi artık kurumsallaşmıştır.

Her yıl binlerce Müslümanın ziyaret ettiği Haremeyn'in imar ve idaresi Osmanlı Devleti için bir prestij meselesi idi. Haremeyn ahalisi devlet hazinesi için toplanan vergilerden ve askerlik görevlerinden muaftı. Buna rağmen, Haremeyn, sürekli devlet hazinesinden ve Mısır başta olmak üzere devletin çeşitli yerlerinde kurulan vakıflardan aynî ve nakdî olarak desteklenerek, imarı için hiç bir fedakarlıktan kaçınılmıyordu. Hatta bunun için Osmanlı devlet merkezinde, Haremeyn vakıflarını idare edecek olan özel bir nezaret de kurulmuştu ${ }^{15}$.

\section{3- Haremeyn'e Giden Yolların Bakımı ve Onarımı}

Şüphesiz gelişmenin birinci şartı ulaşımı sağlayan yollardır. Bu yüzden Osmanlı Devleti öncelikle Haremeyn'e giden yollar ile ilgilenmiştir. 1457 yılında hacca giden bir alim hac yolunda, özellikle su kuyularının harap olduğunu görerek Fatih Sultan Mehmet'e haber vermiştir. Nitekim Fatih Sultan Mehmet de hacıların yol güzergahında su yokluğundan çektikleri eziyeti ortadan kaldırmak maksadıyla yol ve su havuzlarının tamiri için -o sırada bu bölgelere hakim olan- Memluk sultanı Seyfüddin İnal'a yazarak izin talep etmiştir. Fatih Sultan Mehmet, bu konuda istediği izni alamamasına ve Osmanlı-Memlük ilişkilerine olumsuz yansıyacağını bilmesine rağmen yine de yolların tamiri için işçiler göndermişti ${ }^{16}$. Bu ilk girişimden yıllar sonra Mısır Osmanlı idaresine girince Osman11 Sultanları Haremeyn'in himayesini ve oraya ulaştıran güzergâhların sorumluluğunu resmen üstlenmişlerdir ${ }^{17}$.

Hac güzergâhlarının birincisi Anadolu hacılarının da kullandığı Şam-Medine arasında takriben 1200 km.lik yoldur. Coğrafi özellikleri bakımından bu güzergâh üç aşamadan meydana gelmekteydi. Birincisi hacıların muhtelif bölgelerden gelip ilk toplanma yerleri olan Müzeyrib sahrasından Maana kadar; ikinci aşama ise Maan'dan Medain Salih'e kadar olan kısımdı. Üçüncü aşama ise Hicaz sınırları içinde kalmaktaydı. Medine'den Mekke'ye kadar uzanan başka bir güzergah da bulunuyordu. Ayrıca Mağrib hacılarının geldiği Cidde-Yenbu-Medine arasındaki

15 Burada Osmanlı merkezinin Haremeyn'in imarına katkıları, 16 ve kısmen 17. yüzyıllardan seçilen örnekler üzerinden ele alınmaktadır. Daha sonraki asırlar ise daha geniş çalışmaların konusudur. Nitekim 19. yüzyıla kadar sürdürülen klasik idare biçimi, 1840 yılında Hicaz vilayeti teşekkül ettirilerek yeniden şekillendirilmiştir. Bu sırada Haremeyn'e merkezden gönderilen görevliler de artmış ve modern manada bir vilayet meydana getirilmiştir. Yeni görevler de çeşitli ihtisas alanlarına göre belirlenmiştir. Şüphesiz bütün bu hareketlilik ve değişim Haremeyn'in imar ve gelişmesine Osmanlı tarihi boyunca önemli katkılar sağlamıştır.

16 Âşıkpaşazâde, a.g.e., s. 258: Şehabeddin Tekindağ, "Fatih Devrinde Osmanl1-Memlüklü Münasebetleri”, İstanbul Üniversitesi Edebiyat Fakültesi Tarih Dergisi, say1 30 (1976), s.77.

17 Feridun M. Emecen, Imparatorluk Çă̆ı 'nın Osmanlı Sultanları I, İstanbul 2011, s. 92. 
yol güzergâhı da Hicaz idaresinin sorumluluğundaydı. Pek çok konaktan meydana gelen bu güzergâhların her bir konağında, şartlara göre küçük bir kale veya karakol, ayrıca su ihtiyaçlarını karşılayacak havuzlar yapılmıştı. Her yıl hac mevsiminde geçecek hacılara hizmet verecek şekilde bu konaklarda "Huddamân-i Bürke"18 veya "Huddamân-i Kal'a" adı ile görevliler bulundurulmaktayd $1^{19}$. Hac yolu güzergâhında yaşayan kabilelerden seçilen bu görevlilere hizmetleri karş1lığında her yıl sürre ile tahsisat gönderiliyordu. Aynı zamanda su havuzları ve kalelerde tamir gereken yerler de her yıl etraftaki eyaletlerin beylerbeyi (daha sonra valileri) aracılığ 1 ile yapılmaktaydı. Tabii olarak bu faaliyetler bölgeye bir imar hareketliliği de getiriyordu. 1632 yılında bu güzergâhı geçen Abdurrahman Hibrî sadece altı kalenin varlığından söz ederken ${ }^{20}$; 1672 'de aynı güzergâhtan giden Evliya Çelebi 13 kalenin adını vermektedir ${ }^{21}$. Bugün birçoğunun yeri belli ve kalıntıları mevcut olan Şam-Medine arasında, genellikle dört duvardan oluşan 20 civarında büyük-küçük kalenin ve su havuzlarının (bürke) varlığı bu güzergâhta Osmanlı asırlarında sürekli artan imar faaliyetine delalet etmektedir.

Güvenliği sağlamak için yollarda yapılan çalışmalar ve buralarda edinilen tecrübeler aynı şekilde Medine ve Mekke'ye ulaştırılmaktaydı. Bu yollar sadece hacıların güvenliğini sağlamıyor, Mekke ve Medine'nin kalkınmasını ve imarını sağlayacak malların da taşınmasına ve ticaretin gelişmesine imkan veriyordu. Şam-Medine hac yolu sadece hacıların yolu değildi. Aynı zamanda gerek hac kafilesi ile birlikte ve gerekse diğer zamanlarda Haremeyn'e ticari malların taşınması için kullanılan bir ticaret yolu idi. Buradan taşınan mallar ile özellikle Medine'de ciddi imar faaliyetleri sürdürülebiliyordu. Kuşkusuz yolların güvenliğgi kadar her yıl bu güzergâhta hacıların ve yüklerinin nakliyatı için bölgede yaşayan kabilelerin develerinden istifade etmek maksadıyla ayrı bir organizasyona ihtiyaç duyulmakta ve buna büyük önem verilmekteydi ${ }^{22}$.

Diğer taraftan denizden gelen ve Mağripli hacıların yolu olan Cidde-Mekke yolunun güvenliğinin daima sağlanması da bölgenin imarı açısından çok büyük

18 Genellikle güzergâhta yaşayan bedevi kabilelerine verilen bir görev idi. Su kuyuları ve havuzlarının temizlenmesi ve su temini bu görevlilere havale ediliyordu. Elimizdeki belgeler 17. Yüzy1ın sonlarında bunun kurumlaştığını açıkça ortaya koymaktadır. Mesela bu görevleri karşılığında güzergâhtaki Beni Sahr kabilesine gönderilen sürre için bak: BOA, EV. HMK.,192, s. 22.

19 Geç dönem bir Urban Sürre Defteri'ne göre; çeşitli kalelerin hadimleri olarak (Huddaman-1 kal'a) gözüken bedevilere, Cuayman kalesinde on yedi kişiye 445 kuruş; Muazzam kalesinde dokuz kişiye 400 kuruş; Medain kalesinde sekiz kişiye 210 kuruş; Abyâr el-Ganem'de dokuz kişiye 844 kuruş; Hediyye Eşmesi mevkiinde on dört kişiye 720 kuruş; Zahru'l- Akâbe'de yedi kişiye 385 kuruş; Mafrek'te bir şeyhe 200 kuruş; Zerka'da iki kişiye 150 kuruş ödeme yapılmıştır. BOA, EV. HMK. 2422, s. 34-36.

20 Abdurrahman Hibrî, "Menâsik-i Mesâlik" (Neşr. Sevim İlgürel), İ.Ü..Edebiyat Fakültesi Tarih Enstitüsü Dergisi, Sayı: 6 (Ekim 1975), s. 110-128.

21 Evliya Çelebi, Seyahatnâme, İstanbul 1935, IX, 565-620.

22 BOA, $M D, 12 / 361$. 
önem arz ediyordu. Osmanlı Devleti, hac güzergâhında bazı bedevi kabileleri, güvenliği sağlamak veya çeşitli konaklarda hacıların ihtiyaç duyduğu malları depolamak ve hatta pazarlar kurmak için görevlendirmişti. Bunun için devlet onlara sürre ile birlikte urban tahsisatı denilen ödemeler yapıyordu. Bu tür ödemeler ve bireysel ticari faaliyetlerin de hac mevsiminde Şam'dan başlayarak, Medine ve Mekke'ye kadar uzanan iktisadi bir canlılık meydana getirdiğinde kuşku yoktur.

Hac yolu güzergâhlarındaki en büyük tehlike bedevilerin hac kafilelerine saldırmasıydı. Bu güzergâhta yaşayan bir kısım kabileler hac hizmeti vererek bir kısmı da yağma ile yaşamayı adet edinmişti. Bu yüzden bahsedilen kaleler de çoğunlukla güvenlik veya hacılara zahire stoklamak amacı ile inşa edilmişti. Ancak devlet bununla yetinmemiş, özellikle hac mevsiminde problem çıkaran saldırgan bedevileri güvenliği ihlallerinden dolayı şiddetle cezalandırmıştır. Kaynaklarda bunun pek çok örnekleri bulunmaktadır. Hac kervanı güvenliğini sağlamak için hac kafilesine düzenli askerler ve hatta topçular ilave edilmekte ve Şam beylerbeyi, kadı ve defterdarlar hac kafilesinin güvenliği için sıkı sıkı uyarılmaktayd ${ }^{23}$. Mesela Ağustos 1559'da Şam beylerbeyine gönderilen bir hükümde, yol güzergâhındaki bedevi Arapların saldırma ihtimali dikkate alınarak, eskiden beri hacılar ile gönderilen yüz elli sipahinin yüze indirildiğini fakat o yıl güvenlik için bu sayının yeniden eskisi gibi yüz elliye çıkarılması emredilmektedir ${ }^{24} .1565$ yılında Şam beylerbeyine yazılan bir başka hükümde de hacıların korunması için kullanılacak yeniçeri ve sipahi sayısının Şam defterdarı Murad'ın emîrülhaclığ zamanındaki sayı ile aynı olmasının talep edilmesi bu konunun sürekli gündemde tutulduğunu göstermektedir ${ }^{25}$. Muhtemelen asker sayısı artması Şam beylerbeyine ekstra bir yük getirmekteydi ve zaman zaman bu sayının eksiltilmesi yoluna gidilmekteydi. Buna karşılık devlet merkezi durumu sık1 takip etmekte ve bu konuda gerekli emirler yenilenmekteydi. 18 Temmuz 1571 tarihinde Vezir Pertev Paşa'ya yazılan bir emirde hac kafilesini koruma görevi için iki yüz yeniçeri ve yüz sipahi gerekli olduğunun bildirilmesi yol güvenliği işinin artık kurumlaştığını ifade etmektedir ${ }^{26}$.

Bu uygulamalar her sultan döneminde daha da artarak devam etmiş ve kurumlaşmıştır. Süvari birliklerinden oluşturulan askeri bir birlik bu işe tahsis edilmiştir. Kurumlaşan bu birliğe Cerde, birliği idare edene de Cerde Başbuğu adi verilmişti. 17. Yüzy1la gelindiğinde bu birlik Kudüs, Sayda, Trablusşam veya Şam'dan idare edilecektir ${ }^{27}$. Bu askeri birliğin temel görevi hac kafilesinin Şam'dan Hicaz'a güvenli bir şekilde gidip gelmesini sağlamaktı. Askerleri genelde çevredeki urbandan/bedevi Araplardan temin edilen bu birliğe yapılan harcamalar, dolaylı

23 BOA, $M D, 12 / 358,361$.

24 BOA, $M D, 3 / 189$.

25 BOA, $M D, 5 / 509$.

26 BOA, MD, 12/918.

27 Mehmet İpşirli “Cerde”, TDVIA,1993, VII, 392. 
olarak, Şam'dan hicaza kadar önemli bir iktisadi hareketlilik de sağlıyordu. Aslında gerek bu birliğin ve gerekse emîrülhaccin urbandan kiraladığı develer de hem bölge ekonomisini canlı tutuyor ve hem de yıllık fiyatlandırma politikasını belirliyordu ${ }^{28}$. Bu coğrafyada diğer üretimlerin zayıflığı dikkate alındığında hac vesilesiyle Hicaz'a giren malların çokluğu ayrıca tedavüle sokulan nakit paranın önemi açıkça ortaya çıkmaktadır. Tabii olarak bu durum hem bölge ekonomisini canlı tutmakta ve hem de imara katkı sağlamaktadır.

Askeri birliğin hacılar ile Haremeyn'e kadar gitmesi sadece bir yol güvenliği meselesi değildi. Onlar aynı zamanda bölgede iktisadi bir hareketlenme sağlıyorlardı. Cerde birlikleri için kalacak yerlerin hazırlanması, ihtiyaçlarının karşılanması Haremeyn'in ekonomisine bir canlılık getirdiği gibi, askerin ve görevlilerin beraberinde getirdiği bir takım yenilikleri de Haremeyn'e ulaştırdığı muhakkaktı.

\section{4- Saltanatın Görünürlüğü: Haremeyn Vakıfları ve İmar Faaliyetlerine Katkıları}

Osmanlı Devleti’nden önce de Müslüman devletler ve yöneticileri Haremeyn için birçok vakıf kurmuşlard $1^{29}$. Memlukler zamanında çoğunluğunun akarı M1sır'da idi. Ancak Haremeyn'in henüz Osmanlı idaresine girmediği yıllarda bile -Anadolu'da- Konya civarında Karamanlı hanedanı ile Osmanlıların ilk fethettikleri Balkan topraklarında da Haremeyn için vakıflar kurdukları bilinmektedir. Daha fazla araştırmalara ihtiyaç duyulmakla birlikte, şimdilik ilk kurulan Haremeyn vakfının Sultan II. Murat zamanında olduğu yukarıda zikredilmişti. 16. yüzyılın ikinci yarısına doğru ise Osmanlı topraklarında Haremeyn için kurulan vakıfların sayısı hızla artmıştır. Hatta zaman içinde devlet bu vakıfları idare etmek ve gelirlerini düzenli bir şekilde Haremeyn'e göndermek için özel bir idare kurmak zorunda kalmıştır. Haremeyn vakıfları, başta Sultan ve yakınları, Sultan anneleri, devlet adamları ve halkın zengin hayırsever kimseleri tarafindan kurulmaktaydı. Vakıfların kuruluş şartları arasında mutlaka Mekke ve Medine ahalisi ve fukarasına yapılacak nakdî ve aynî yardımlar zikredilmekteydi ${ }^{30}$.

28 17. yüzyılın son çeyreğinde ve 18. yüzyılın başında nakliyat için 26.066,5 kuruşluk ödeme 18 . Yüzyılın ilk yarısına doğru yaklaşık dört kat artmıştır. Ayrıca Şam yakınlarındaki Müzeyrib sahrasından Medine'ye kadar hac güzergâhındaki kalelere taşınan yükler hakkındaki bir liste bu konuda önemli fikirler vermektedir. Develerle taşınan toplam 4429 yük için 17065 kuruş ödeme yapılmıştır: BOA, Topkapı Sarayı Defterleri (D) 23 'den nakleden Faruk Doğan,. "18 ve 19. Yüzyıllarda Şam-Medine Hac Yolu Güvenliği: Cerde Başbuğluğu”, Tarih Okulu Dergisi, Eylül 2013, Y1l 6, sayı XV, s. 136.

29 Haremeyn için geniş bir vakıf ağı kurulmuştur. Bu konuda hâlâ pek çok araştırmalara ihtiyaç bulunmaktadır. Ancak mücmel bir çalışma için bak: Mustafa Güler, Osmanlı Devleti'nde Haremeyn Vakıfları (XV.-XVII. Yüzyıllar), İstanbul 2002.; Ayrıca yeni bir envanter için bak. Evgeni Radushev ve diğerleri, Inventory of Ottoman Documents About Waqf Preserved in the Oriental Department at the St Cryril and Methodius National Library, part I, Sofia 2003.

30 Âş1kpaşazâde, a.g.e., s. 252; Suraiya Faroqhi, Hacılar ve Sultanlar, İstanbul 1995, s. 83.; Evgeni Radushev ve diğerleri, a.g.e., s. 21. 
I. Selim, Mısır'ı Osmanlı topraklarına kattığında Memlukler zamanından devralınan Haremeyn vakıfları da yeniden düzenlendi. Ardından bunlara I. Selim ve onu takip eden diğer sultanlar tarafindan yenileri ilave edildi. Örneğin Kanuni Sultan Süleyman hanımı Hürrem Sultan adına Haremeyn için bir imaret kurdurmuştu ve giderleri de Misır'dan vakfedilen akarlardan karşılanmaktayd $1^{31}$. Her yıl Mısır'dan Haremeyn muhtaçlarına aynî olarak, "bulgurluk buğday" anlamına gelen ve deşî̧se denilen yardımlar gönderilmekteydi. Sultanlara ait hububat vakıflarına Deşişe-i Kübra adı veriliyordu. III. Murad zamanında vakıflardan gelen gelirlerin daha da artması ile Haremeyn'e nakdî yardım yapan Küçük Deşişse vakfinı kurulacak ve daha sonra diğer vakıflar da bunun üzerinden idare edileceklerdir ${ }^{32}$.

Aynı şekilde Haremeyn adına Anadolu'da ve Balkanlarda kurulan vakıflar hem yıllara göre hızla artış göstermiş ve hem de buralardan Haremeyn'e sağlanan katkılar çoğalmıştır. Zaman zaman kıtlık, savaş gibi sebepler ile bu gelirlerde azalma görülmekte, bazen de görevlilerin ihmali ile bu gelirler kanuni sahiplerine ulaştırılamamaktaydı. Osmanlı Sultanları bu durumda tedbirlere başvurmakta ve sorumluları da muhakeme ettirmekteydiler.

Kurulan vakıfların gelirleri, Haremeyn'de başta ahalinin ihtiyaçları olmak üzere cami, medrese, kütüphane, hastane, sebil, su sarnıçları ve kuyuları, yol yapımı ve diğer imar faaliyetlerine harcanıyordu. Özellikle Haremeyn'de hacca hizmet veren mekanların tamiri ve 1slahı Kâbe'nin temizliği, aydınlatılması güzel kokuların serpilmesi ile haccı kolaylaştıracak diğer hizmetlerin yapılmasına harcama yapmak da bu vakıfların amaçları arasındaydı. Bu maksatla bazı vakıflar özellikle hacıların konaklamasına imkan veren ribatlar ve tekkelere tahsis edilmiştir. Haremeyn'de yapılan bir cami, medrese veya kütüphanenin yaşamasını sürdürmek üzere yine ona bağlı gelir getiren dükkanlar ve hanlar da yapılarak vakfedilmekteydi. Bu da Mekke ve Medine şehirlerinin gelişmesine doğrudan katkı sağlıyordu. Haremeyn'de, Mescid-i Haram, Mescid-i Nebevî veya diğer medrese ve kütüphanelere geliri tahsis edilmiş pek çok başka binalar bulunmaktaydı. İhtiyaç duyulduğunda devlet, masrafları vakıf gelirlerinden veya hazineden karşılayarak, bunların tamirlerini veya genişletmelerini yapmaktaydı. Osmanlı arşivlerinde bununla ilgili pek çok belgeye rastlamak mümkündür.

Yıllar geçtikçe artan vakıf hizmetlerinin düzen altına alınması maksadıyla 1586 yılında Evkaf-1 Haremeyn Nezareti kuruldu. Bu nezaretin başına da Sultan ile doğrudan iletişimi olan Darüssaade Ağası getirildi. Bu vakıflardan toplanan gelirlerin bir bölümü sürre çıkarma zamanında Haremeyn'e gönderilir, geri kala-

31 Mısırdan Mekke fakirlerine her yıl 1500, Medine fukarasına da 14000 erdeb buğday (deşişe-i amme) gönderilmekteydi. Bunun 1500 erdep artırılmasına dair 1559 sonlarında Misır beylerbeyine gönderilen bir hüküm için bak: BOA, $M D$ 3/542.

32 Uzunçarş1l1, a.g.e., s. 15.; Suraiya Faroqhi, a.g.e., s. 88.; Seyyid Muhammed, "Deşîșe" TD$V \dot{I} A, 1994$, IX/214-15. 
nı da sarayda muhafaza edilirdi. Bu hazineden sultanın izni olmadan kimse harcama yapamazdı. Evkaf-i Haremeyn Nezareti hızla büyüdü ve yeni memuriyetler de ihdas edildi. Gelirleri artan vakıflar için özel muhasebe sistemi geliştirildi. Kayıtları ise çok özenli tutulmaktayd1 ${ }^{33}$.

Başta Mısır, Anadolu ve Balkanlar olmak üzere Osmanlı Devleti'nin her tarafına yayılmış olan Haremeyn vakıflarının her yıl aynî veya nakdî yardımlarının takibi ciddi bir organizasyonu gerektiriyordu. Gösterilen özene rağmen, yerel yöneticiler veya vakıf mütevellileri ile diğer bazı görevlilerin, ihmalkar davrandıkları veya zimmetlerine para geçirdikleri de oluyordu. Özellikle Misır'dan gönderilen deşîşe buğdayının zamanında ve belirlenen miktarda gönderilmemesi pek çok şikayetlere konu olmaktaydı. Aslında on altıncı yüzyılın yazışmalarına konu olan bu şikayetler bize vakıfların işleyişi ve büyüklükleri hakkında da önemli bilgiler vermektedir. Vakıflardan gönderilen aynî ve nakdi yardımların dışında her yıl devlet bütçesinden de Haremeyn'e gönderilen paralar ile hem hac ibadeti organize ediliyor hem de bölgenin imarı sağlanıyordu. Suraiya Faroqhi çalışmasında 1527 ile 1691 yılları arasındaki devlet bütçesi ile hacılara ve Haremeyn'e yapılan harcamaları karşılaştırmıştır. Buna göre merkezî bütçeden yapılan yardımlar merkezî genel bütçenin \% 1.5-2sine tekabül etmektedir ki, bu çok ciddi bir rakam olarak ortaya çıkmaktadır. Ayrıca Mısır bütçesinden önemli miktarda bir payın Haremeyn için ayrıldığ $1^{34}$ düşünüldüğünde devletin merkezî bütçesinden ve ona ulaşması beklenen gelirlerden önemli bir bölümünün hac ve dolayısıyla Haremeyn' in imarına ayrıldığı kolaylıkla anlaşılabilir. Yapılan bu yardımların birçoğu öncelikle Medine ve Mekke'deki şahıslara ve ihtiyaç sahiplerine gitmekteydi. Fakat gönderilen bu meblağların orada harcandığı dikkate alınırsa, bölgenin gelişmesinde doğrudan katkısı olduğu da bir gerçektir. Yani merkez bölgeye bir bakıma vakıflar ve sürre üzerinden dolaylı kalkınma yardımı yapmaktaydı. İmar amaçlı büyük inşa işlerinde ise yapılan keşfe göre umumiyetle özel bütçeler hazırlanmakta ve işe uygun tahsisatlar verilmekteydi.

\section{5- Mekke'de İmar Faaliyetleri}

Kuşkusuz Osmanlı Devleti'nin Hac vesilesi ile önem verdiği en önemli hususlardan biri hatta en başta geleni Harem-i Şerif ve etrafının imarı idi. Osmanl1lar bunu dini bir görev olarak benimsemiş ve bu konuda hiçbir fedakârlıktan kaçınmamışlardır. Harem-i Şerif'in imarı için bütçe tahsisinden sonra inşaat ve tamir için ihtiyaç duyulan malzeme temini yoluna gidilirdi. Hicaz'dan bulunmaması halinde de dışarıdan getirilirdi. Aslında hiçbir zaman Mekke'de inşaat malzemesi yeterli değildi. Bu yüzden çoğu kere büyük bir gayretle malzemeler

33 Ş. Tufan Buzpınar, Mustafa S. Küçükaşçi, "Haremeyn” Türkiye Diyanet Vakfi İslam Ansiklopedisi, XVI, 153-157. ; Mustafa Güler, a.g.e, s. 172-177.

34 Suraiya Faroqhi, a.g.e., s. 86-89. 
dışarıdan getirilirken de büyük bir ekonomik faaliyet gerçekleştirilirdi. Kereste, demir, tuğla, mermer gibi malzemelerin en iyi cinsi Osmanlı Devleti'nin hemen her yerinden ve ihtiyaç duyulduğunda Hindistan'dan da getirilmekteydi. Ancak zaman ve maliyet hesaplamaları yapılarak, bazen Mescid-i Haram'ın tamiri için gerekli malzemeler İstanbul'da imal edilerek, Mekke'ye sevk ediliyor ve orada sadece yerine monte edilmesi sağlanıyordu. İşçi ve ustalar Şam'dan veya M1sır'dan getirilmekteydi. Ancak yapılacak işin özelliğine göre Anadolu'dan da ustalar gönderilmekteydi ${ }^{35}$.

\section{a) Harem-i Şerif ve Etrafında Düzenlemeler}

Bilindiği gibi Mescid-i Haram'da Osmanlılar öncesinde de müteaddit tamirler yapılmıştır. Haremeyn'in Osmanlı idaresine geçmesinden itibaren de Harem-i Şerif değişik sultanlar tarafından ya tamir edilmiş ya da yenilenmiştir. Belgelere yansıyan bilgilerdeki usule göre, Mescid-i Haram'daki tamir veya yenileme ihtiyacı, Mekke emirleri tarafından İstanbul'a bildirilir, bu maksatla gerekli ihtiyaçlar ve maliyetler belirlendikten sonra işe başlanırdı. Kayıtlara göre özellikle tavaf yerinin aşınması, Kâbe'yi zaman zaman sel basması, Kâbe duvarlarının zarar görmesi gibi gerekçeler ile sık sık tamiratlar yapılmaktaydı. Hemen hemen her üç yılda bir Harem'in sathı yenilenmekteydi. Ancak bazı dönemlerde bu durum daha uzun zaman aralıkları ile de yapılabiliyordu. Gerek bu konularda ve gerekse Harem-i Şerif'in etrafinda yapılan düzenlemeler ile ilgili Osmanlı arşivlerinde pek çok yazışmalar bulunmaktadır. Bu yazışmalardan anlaşıldığına göre, yapılacak masraflar hiçbir tartışma yapılmadan merkezden veya emir verilen eyaletlerin bütçesinden doğrudan karşılanıyordu ${ }^{36}$.

Kâbe'nin temizliği ve aydınlatılması için de sürekli yeni düzenlemeler yapılmakta ve gerektiğinde kandiller ve yağları için tahsisatlar arttırılmaktaydı. Zaman zaman bu maksatla tahsis edilen vakıfların mütevellilerinin görevlerini yapmadığ 1 veya bir kısım suiistimallerin yapıldığına dair şikâyetler İstanbul'a kadar ulaşmaktaydı. Mesela 1567 yılında Mekke kadısına yazılan bir emirde Sultan Gavri, Sultan Çakmak ve Sultan Kayıtbay evkafından bu maksatla harcanması gereken 500-600 altının, mütevelliden olan Kadı Hüseyin tarafından kendi zimmetine geçirildiği iddia edilerek, aydınlatma ile temizlik hizmetlerinin aksadığ şikâyetleri yapılmıştır. Gönderilen emirde meselenin tetkiki ve Mısır'da bölük halkından güvenilir bir mütevellinin tayin edilmesi talep edilmiştir ${ }^{37}$. Nitekim bu şikâyetler etkili olmuş olsa gerekir ki, 1568 yılında yine Mekke kadısına gönderilen başka bir hükümde; Harem-i Şerife altın kandiller, balmumu ve zeytinyağ 1 gönderildiği bildirilmiş ve bu gönderilen kandiller ve yağların kayıtlarının tutul-

35 A.g.e., s. 104-105.

36 Bu tür bazı belgelerin değerlendirilmesi için bak: Tuğba Aydeniz, a.g.tez, s. 81-82.

37 BOA, MD 7/896. 
mas1 emredilmiştir ${ }^{38}$. Böylece bir taraftan eksiklik giderilirken diğer taraftan da muhtemel dedikoduların önü alınmak istenmiştir.

Bu tür faaliyetler, İstanbul'daki inşaat teknolojisini Haremeyn'e taşıdığı gibi, kaliteli malzemenin de kullanımına imkan vermekteydi. Özellikle tezyinatta bol bol altın ve gümüşün kullanılması, buraya verilen önemin bir göstergesidir. Tabii olarak bu faaliyetler ve Haremeyn'e taşınan malzemeler genel olarak sosyal hayatı ve çevreyi de etkiliyor ve adeta toplu bir imar fikrinin gelişmesini sağlıyordu.

Hicaz'da Osmanlı idaresinin başlamasının ardından ilk yarım asır boyunca Mescid-i Haram'da pek çok değişiklik yapılmıştır. Bunun yanı sıra Kanuni Sultan Süleyman Mescid-i Haram'ın hemen yanı başında dört mezhep için dört medrese yaptırmış ve müderrisler tayin etmiştir. Mescid-i Haram ile bütünleştirilen bu yapılar, bir bakıma Osmanlı mimari anlayışının bölgeye taşınmasını temsil etmektedir. Kanuni Sultan Süleyman, Mescid-i Haram'in bazı minarelerini tamir ettirdiği gibi, Abbasi Halifesi El Mansur'un yaptırdığg ve yıkılmak üzere olan minareyi de yeni baştan inşa ettirmiştir. İnşa edilen minareler mimarı bakımdan Mekke'ye yeni bir mimari tarzı da getirmekteydi. Nitekim var olan altı minareye ilave olarak inşa edilen yedinci minare de bunun bir göstergesidir ${ }^{39}$.

Osmanlı mimarı tarzını Harem-i Şerife taşıyan en önemli imar faaliyeti hiç kuşkusuz Kanuni döneminde fikri ortaya atılan ama daha sonra hayata geçirilen Kâbe'nin etrafının genişletilmesidir. Bu anlamda Mescid-i Haram'da kapsamlı bir tamir ve genişletme faaliyetinin ancak II. Selim zamanında (1566-1574) başladığı söylenebilir. Kaynakların zikrettiğine göre, 1571 yılında Mekke'de meydana gelen bir selin Mescid-i Haram'a ve etrafina zarar vermesi üzerine Kâbe'nin harap kısımlarını yenileme veya tamir fikrini ortaya çıkarmıştır. Yapılacak inşaatın planlarının dönemin meşhur mimarı Mimar Sinan'ın yaptığı da rivayetler arasındad $1 r^{40}$. Ancak maalesef bu girişim detaylarına vakıf değiliz. Sultan II. Selim döneminde başlatılan çalışmalar, Sultan III. Murad (1574-1595) zamanında tamamlanabilecekti. 1571 tarihinde Vezir Sinan Paşa'ya yazılan bir hükümde; Harem-i Şerifte tamir edilmesi gereken mermer direklerin ve üstündeki çatının keşfinin yapıldığı ve tamiri için kırk bin flori harcanacağ 1 belirtilerek bu inşaatın geciktirilmeden yapılmasının istenmesi II. Selim' in saltanatının son yıllarında bu konuda hâlâ aktif faaliyetin olduğunu göstermektedir. Ayrıca, Medine'de Ravza-i Mutahhara kubbe ve çatısı ile camlarının tamirini emreden farklı bir hükmün -bir hafta sonra-, 19 Ağustos 1571'de yine Sinan Paşa'ya gönderilmesi Haremeyn imarının o dönemde sıkı bir şekilde takip edildiğinin ve bu konuda Sultanın ısrarc1 olduğunun işareti olarak değerlendirilebilir ${ }^{41}$.

38 BOA, $M D 7 / 955$.

39 BOA, $M D$ 7/ 442; Suraiya Faroqhi, a.g.e., s. 109.

40 Zeki Sönmez, Mimar Sinan Dönemi Türk Mimarlı̆̆ ve Sanatı, Mimar Sinan'ın Mekke ve Medine'deki Eserleri, İstanbul 1988, s. 345-346.

41 BOA, MD 12/ 849, 852. 
$\mathrm{Bu}$ yazışmalar ve tamir taleplerinin Haremeyn'de Osmanlı mimarisinin de uygulanmasına doğru gidildiğini göstermektedir. Bu konuda mahalli ulemanın fikrine başvurulmuş ve önce eski tarzda bir genişletme gündeme gelmiş ise de ardından 400-500 kubbeli bir alanın yapılması tasarlanmıştır. Sonuçta gerek yerel ulemanın görüşleri ve gerekse inşaat imkânları dikkate alınarak, Harem-i Şerif’te tasarlanandan az, 152 kubbeli bir alan inşa edildi ${ }^{42}$ ve Kâbe'nin tavaf alanı genişletildi. Bu genişletme sırasında Müslümanların ibadetlerini daha rahat yapmaları için Kâbe'nin sathı ve tavaf yerinin mermer ile döşenmesi ilk defa gündeme gelmiştir. Suraiya Faroqhi belgelere istinaden görüntünün değişmesi ve ibadethanenin lüks bir mekana dönüşmesi endişesi duyan yerel ulemanın ve Mekkeli Müslümanların bu konudaki isteksizlikleri konunun ertelenmesini gerektirdiğ $i^{43}$ kanaatini serdetmektedir. Ancak daha sonra makam-i İbrahim'in de elden geçirilerek talep edilen uygulamanın yapıldığı anlaşılmaktadır.

\section{b) Çevre Düzenlemeleri}

1572-1576 arasında sürdürülen bu çalışmalar ve kubbeli ilaveler dışında; Kâbe'nin selden zarar gören 19 kapısı yenilenmiştir. Özellikle 1576 yılı sonlarında Kâbe'de Babusselâm yakınlarında taşarak etrafı kirleten su sebebiyle bu çalışmaların hızlandırıldığı anlaşılmaktadır. İlk iş olarak, Veziriazam Sokullu Mehmed Paşa'nın (sadareti: 1565-1579) yaptırdığ medreseden artan kereste ile bu sorunun çözümü yoluna gidilmiştir. Ayrıca Kâbe kapılarının eşikleri yükseltilerek sele karşı sed görevi yapacak merdivenler konulmuştur. Tabii ki bu inşaatın sonunda Mescid-i Haram'ın içi “Allah” lafzı, Hazreti Peygamberin ve ashabının isimleri ve ayetler ile tezyîn edilerek ${ }^{44}$ Osmanlı süsleme sanatı da buraya taşınmıştır.

Aynı sıralarda Harem-i Şerif' in etrafındaki medrese, tekke ve diğer binalarda da tamiratlar yapılmıştır. Kâbe etrafında düzenlemeler veya genişletmeler yapılırken, bazen de çevredeki evlerin sahiplerinden satın alınması ihtiyacı da doğuyordu. Mesela bu maksatla 1584 yılında 20 bin flori tahsisata ihtiyaç duyuldu. Yapılan yazışmalardan bunun karşılandığı anlaşılmaktadır. Fakat ertesi yıl, satın alınıp yıkılan bu evlerin boş alanlarına Hintlilerin kulübeler yaparak yerleştiği şikayetleri İstanbul'a ulaşmıştır. Bunun üzerine Cidde beyi uyarılmış, meydana gelen bu düzensizliğin önlenmesi ve Kâbe ile etrafının temiz tutulması için gereken düzenlemeleri yapması Sancak beyinden özellikle istenmiştir ${ }^{45}$.

Özellikle hac mevsiminde Harem-i Şerif'in ve çevresinin temizliği bir problem olarak ortaya çıkmaktaydı. Zira özensiz bir şekilde atılan çöpler, tuvaletlerin

42 Suraiya Faroqhi, a.g.e., s.110-111'den naklen: BOA, MD 10/ 391; 21/ 553; 48/ 624.??

43 A.g.e., s.112.

44 BOA, $M D$, 7/ 2619; Sadık Eraslan, "Osmanlıların Haremeyn-i Şerifeyn Hizmetleri” Diyanet İlmi Dergi, cilt 35, say1 1, Ocak-Şubat-Mart 1999, s. 216-217.

$45 \mathrm{Bu}$ konudaki bazı yazışmaların değerlendirmesi için bak: Tuğba Aydeniz, a.g.tez, s. 83. 
ve kanallarının tıkanması büyük sorunlar yaratmaktaydı. Mesela 1590 yılında böyle ciddi bir sıkıntı meydana gelmişti. Mescid-i Haram'ın etrafında yer alan Sultan Kayıtbay ve Sultan Gavrî medreselerinin tuvaletleri taşmış ve Babusselam ile Babu'l-Şeybe'ye kadar ulaşmıştı. Ayrıca o yıl yağan yağmurlar biriken bu birikintileri nerede ise Haremin içine kadar taşıyarak, hacıların sıkıntı çekmesine neden olduğu şikâyetleri İstanbul'a kadar ulaşmıştır ${ }^{46}$. Bu konuda derhal tedbirler alınarak söz konusu eski tuvaletlerin kaldırılıp, yenilerinin yapıldığ anlaşılmaktadır.

Harem-i Şerif'te ziyaretçilerin su ihtiyacını karşılayan Zemzem kuyusu ve etrafı da oldukça erken dönemden itibaren bu imar çalışmalarından nasibini almıştır. Sürdürülen çalışmalar ile Abbasiler zamanında elden geçirilmiş olan kuyunun üstüne bir saçak ve bir de kubbe yapılmıştır. Ahşap tavanlar süslenmiş, daha sonra da zemin mermer ile döşenmiştir. Zemzem kuyusu 17. yüzyılın başlarında yeniden elden geçirilip, su çekme sistemi, konulan makaralar ve kovalar ile daha kolay hale getirilmiştir ${ }^{47}$.

\section{c) Yaşama Alanlarına ve Hacıların İhtiyaçlarına Dönük Faaliyetler}

Hac mevsiminde en temel sorunlardan bir tanesi kuşkusuz gelen fakir hacıların konaklamaları ve yeme-içmeleri idi. Bu maksatla Memlukler zamanında yapılan imaretlere ilave olarak, Kanuni Sultan Süleyman'ın hanımı Hürrem Sultan için Mekke'de büyük bir imaret kurulmuş ve geniş para tahsisatları yapılmıştır. Gelen fakir hacılar buralarda kalmakta ve günlük yeme-içme ihtiyaçları da bu imaretlerden karşılanmaktaydı. Aynı yıllarda ünlü vezir Sokullu Mehmet Paşa'nın kurduğu vakıf aracılı̆̆ ile Mekke'de bir hastahane yapılarak halkın ve hacıların tedavisine tahsis edildiği gibi, ücretsiz hizmet veren bir de hamam inşa edilmiştir.

Mekke-i Mükerreme'nin en önemli ihtiyacı su idi. Özellikle bu ihtiyaç hac mevsiminde daha da artmaktaydı. Bu yüzden Osmanlı Devleti bölgeyi idaresine almasının akabinde Mekke'nin temiz su ihtiyacının karşılanması ile de ilgilenmiştir. Bu faaliyetler ya eskiden beri var olan su kanallarının temizlenmesi veya yeni şebekelerin yapılması şeklindeydi. Mekke'ye su taşıyan Aynu Arafat (Cebel-i Arafat Su şebekesi) su şebekesi bozulmuş ve şehir susuzluğa mahkûm olmuştu. Bu yüzden bir taraftan Harem-i Şerif'in etrafının temiz tutulması, diğer taraftan zor bir coğrafyaya sahip olan şehrin birçok noktasına suyun dağıtılması için çalışmalar yapılması gerekmişti. Aynı şekilde 1564 yılında Mısır' dan getirilen malzeme ve ustalar ile Aynu Zübeyd'e suyolu yenilenerek ve bu suya Aynu

46 BOA, $M D$ 67/ 356.

47 Daha geniş bilgi için bak: Mustafa S. Küçükaşçı, “Zemzem”, TDVİA, İstanbul 2013, XLIV, 242-245.; Mustafa Güler, a.g.e., s.68. 
Hanin kanalları da ilave edilerek Mekke bol ve temiz içme suyuna kavuşturuldu ${ }^{48}$.

Tabii su meselesi hemen ve kolaylıkla halledilemedi. Yirmi yıl boyunca çeşitli çalışmaların sürdürüldüğü anlaşılmaktadır ${ }^{49}$. Ayrıca açılan su yollarının sürekli korunmas1 ve temizlenmesi de gerekiyordu. Bu maksatla Osmanlı hayırseverlerinin vakıflarından karşılanan tahsisatlar ile ücretli görevliler istihdam ediliyordu. Mesela 1573 yılında su kanallarının temizliğinde çalışan kırktan fazla kadın bulunuyordu ve bunlar daha önce işe başlamış olan yüz kadından geri kalanları idi. Bunların ücretleri vakıflar tarafindan ödenmekteydi. Hatta daha Kanuni Sultan Süleyman'ın Mekke suyu için de bir vakıf kurduğu bilinmektedir ${ }^{50}$.

Osmanlılar, Mekke'de hac hizmetlerini organize ederken ve gelen hacılara hizmet üretirken esasında şehre de bir düzen sağlıyorlardı. 16. Yüzyılın ortalarında bile Mekke'deki binalar gelen hacıların konaklamasına yetmiyordu. Ayrıca fakir hacıların konaklamaya verecek paraları yoktu. Onlar da çoğu kere Harem-i Şerif'te yatıp kalkıyorlardı. Bu durum tavaf ve ibadetin yapılmasına engeldi. Ayrıca bu düzensizlik Kâbe'nin ve şehrin kirlenmesine ve hastalıklara neden oluyordu. Kanuni Sultan Süleyman, oldukça erken bir dönemde 1555 yılında Mekke Kadısına gönderdiği bir fermanda, (Hürrem) Sultan'ın imaretleri yakınında uygun bir yerin bulunup, satın alınarak, fakirler için kalma yerlerinin yapılmasını emrediyordu ${ }^{51}$. Aynı hükümde fakirler için bir mekanın yapılıp Harem-i Şerif'in "televvüs ve tedennüsten" temizlenmesi talebinin bildirilmesi meseleye verilen önemi göstermekteydi. Aslında bu tür emirler her hac mevsiminde veya şikayet vukuunda yenilenmekteydi. Benzeri emirlerin zemzem yerinin ve abdesthanelerin temiz tutulması konusunda da verildiği görülmektedir ${ }^{52}$. Aslında ne gelen fakir hacıların ikametleri sorunu ve ne de temizlik sorunları hemen ve kolay çözülebilecek bir problem değildi. Ancak daha sonra yapılacak olan imar faaliyetleri ile Sultan III. Murad döneminde sorun kısmen çözülecektir. Fakat bu döneme kadar Osmanlı Sultanlarının hemen her dönemde Haremeyn'in imarı ve çevre

48 BOA, $M D 6 / 435$, Bu konuda Mekke şerifine yazılan hükümde şu ifadelere yer verilmekteydi: “Zikrolunan su Belde-i Tayyibe'ye gelüp cârî olmakdan murâd mukîmân-1 makâm-1 latîf ve mücâvirân-1 Harem-i Şerîf in su bâbında olan muzâyakaları def 'olup fî-sebîli'llâh cenâb-1 cennet-mekânda cârî olmağla tahsîl-i mesûbât [u] sa âdet-i dâreyn müyesser olmakdur” BOA, MD 6 /456.; İnşaat işini yürütmek için Mısır'dan gönderilen İbrahim Bey ve diğer görevlilerin ihtiyaçlarının görülmesi konusunda da hassasiyet gösterilmekteydi. Yazışmalardan anlaşıld1ğına göre Mısır'a giden çalışanların sayısı 50ye yakındı. Ancak çeşitli kaynaklardan bunların sayısının yüzlere vardığını öğrenmekteyiz. BOA, $M D, 6 / 448,450,451$

49 BOA, $M D, 5 / 257,261,391,607,608, M D$ 7/2478, 2479

50 Suraiya Faroqhi, a.g.e., s. 119-120. Kanuni Sultan Süleyman vasiyetinde, su sorunu olan Cidde için de bir su şebekesinin yapılmasını istemiştir. Konu II. Selim döneminde ele alınmış, ancak öngörülen şebekenin yapılması mümkün olmamıştır. Bunun üzerine Cidde'ye ilave su sarnıçları yapılmasına karar verilmiştir. BOA, MD 23/227; Suraiya Faroqhi, a.g.e., s. 120.

51 BOA, $M D 3 / 1088$.

52 BOA, MD 3/ 1089. 
şartlarının iyileştirilmesi için büyük gayret gösterdikleri çok net bir şekilde anlaş1lmaktadır.

Mekke'de Harem-i Şerif'in temizliği için bir dizi tedbirler alınıyordu. Ancak bu tedbirler temizliğin sürekli olması için yeterli değildi. Zira Harem-i Şerif Mekke'nin alçak bir yerinde idi ve etrafa atılan çöpler buraya doğru akmaktaydı. $\mathrm{Bu}$ yüzden Mekke emiri ve kadısına gönderilen fermanlar ile halkın çöplerini şehrin dışına atmaları isteniyordu ${ }^{53}$. Osmanlı belgeleri arasında yer alan bu yazışmalardan Osmanlı Devleti'nin sadece Haremi Şerif ile değil, Mekke şehrinin tamamı ile ilgilendiklerini anlamak mümkündür.

On altıncı yüzyılda Harem-i Şerifte yapılan bir diğer düzenleme de Safa ve Merve arasındaki Sa'y alanının düzenlenmesidir. 1587 tarihli belgelerden anlaşıldığına göre tüccarlar, mallarını burada sergiliyor ve Sa'y ibadetinin yapılmasını zorlaştırıyorlardı. Hatta Safa ile Merve arasında yerleşik dükkanlar bile oluşmuştu. Osmanlı yönetimi gelen şikayetleri dikkate alarak en azından burada yeni dükkanların açılmasına engel olmuştur ${ }^{54}$. Aslında benzeri düzenlemeleri genel olarak şehrin içinde de yapmaktaydılar. Hacıların ihtiyaçlarını karşılayan ve ticari hayatın devamına imkan veren dükkanların kaldırılması mümkün değildi, fakat bu dükkanların insanların geçişlerini engellemeyecek yerlerde olmasına ve pazarların Harem-i Şerif'in uzağında kurulmasına özen gösterilmekteydi. Osmanlı yönetimi baştan itibaren Mekke'yi, hac ibadetinin sağlıklı bir şekilde yapılmasına uygun olarak planlamaya önem vermekteydi. Bu maksatla devlet Mekke emirleri, ulema ve yerli eşraf ile tüccarları muhatap alarak yeni düzenlemeler hayata geçirmeye çalışıyordu. Bu yüzden Mekke'de 16. yüzyıl boyunca pek çok altyapı yatırımının hayata geçirildiğini Osmanlı mühimme kayıtlarından takip etmek mümkündür.

On yedinci yüzyılın başına gelindiğinde hem Mekke'de hem de Harem-i Şerifte yeniden bir dizi düzenleme ve tamirat planlanmıştır. Ancak Kâbe'nin eski binasına dokunulmamıştır. En kapsamlı tamirat III. Murad zamanında yapılmış olsa da sürekli yağan yağmurlar ve seller Kâbe'nin duvarlarına ve çatısına zarar veriyordu. Bu yüzden yıpranan binaya on yedinci yüzyılın başında son müdahale 1603 yılında tahta geçen I. Ahmet zamanında yapılacaktır. Söz konusu tarihte yıpranan duvarlar, çatı ve Kâbe oluğu onarıldı ve Kâbe duvarları dışarıdan üstünde altın ve gümüş süslemeler olan demir kemerle kuşatılarak sağlamlaştırıldı. $\mathrm{Bu}$ tamirata ve düzenlemelere 1630 yılında meydana gelen büyük sel bir kere daha zarar verdiğinde, Kâbe'nin yeniden inşası gündeme geldi. Tahmin edileceği gibi bu yeni durum ulema arasında uzun tartışmalara neden oldu. Nitekim bütün bu tartışmalar İstanbul'a ulaştırıldı. Bu konudan anlayan mimarlar görevlendirildi. 
Onların keşif ve raporları da hem Mekke'de hem de İstanbul'da yeniden tartışıldi. Nihayet Sultan IV. Murat hem Cidde sancak beyini hem de Misır valisini görevlendirerek çalışmalar başlatacak ve Kâbe'yi yeniden inşa ettirecektir. Ancak bütün bu yapılanlar bu makalenin sınırları dışında tutulmuştur.

\section{6- Medine'de İmar Faaliyetleri}

Medine gerek Hazreti Peygamberin kabrine ev sahipliği yapması ve gerekse ona komşu olmak isteyen mücavirlerin çokluğu nedeni ile İslam tarihi boyunca imar faaliyetlerinden geniş bir şekilde nasibini almıştır. Tabii olarak şehirde ilk dikkatleri çeken mekanın şehrin genelinden ziyade Mescid-i Nebevî olduğu muhakkaktır. İlk imar faaliyetlerinin buradan başlatılması ve buranın merkez alınarak şehrin geliştirilmesi zaten eski bir gelenekti. Osmanlılar da bunu aynen takip etmişlerdir.

\section{a) Mescid-i Nebevînin İmarı ve Etrafında Düzenlemeler}

Bilindiği kadarı ile Mescid-i Nebevî'de Osmanlı padişahlarından ilk imar yapan Kanuni Sultan Süleyman'dır ${ }^{55}$. Tahta geçtiği yıllarda, oldukça bakımsız olduğu anlaşılan Mescid-i Nebevî'nin tamiri için Misır beylerbeyine talimatlar vermiştir. Mısır beylerbeyi de buraya mimar ve ustalar yollayarak Harem-i Nebevî'yi inceletmiştir. Nitekim gerekli keşif ve istişareler yapıldıktan sonra ancak 1534 yılında Babu's-selam yıkılarak yeniden mermerden yapılmıştır. Altı sene sonra 1540 yılında da Babu'r-Rahme'den Şekliye minaresine kadar olan duvar ile mezkur minarenin batısında kalan duvar ve minare de yıkılarak yeniden inşa edilmiştir. Yine Babu'n-Nisa' dan Aher-i hareme kadar olan şark duvarı minaresi ile birlikte yeniden inşa edilmiştir. O zamana kadar adı Şekliye olan bu minare yeniden inşasından sonra Süleymaniye minaresi olarak anılmaya başlanmıştır ${ }^{56}$. Ayrıca tüm minarelerin alemleri de bu sırada yenilenmiştir. Aynı dönemde Hz. Peygamberin kabrinin bulunduğu mekan kandiller ile döşenmiş, Mescid-i Nebevî'nin minberleri ve mihrapları yenilenmiştir. Bunun yanında ayrıca Kanuni Sultan Süleyman adıyla anılmaya başlanan bir de minber inşa edilmiştir ${ }^{57}$. Kanuni'nin yaptırdığı bir diğer yenilik de Babu'r-Rahme kapısının sağ ve sol taraflarına ayet, hadis ve naatlarla birlikte kendisine kadar olan tüm Osmanlı padişahlarının adını yazdırmasıdır.

II. Selim zamanında Mescid-i Nebevî'nin ve Medine'nin temel ihtiyaçları olan konulara ağırlık verilmiştir. Bilindiği üzere bu sorunların en önemlisi su sorunudur. Bu doğrultuda Ayn-1 Zerka suyolları tamir edilerek Medine'nin değişik

55 Nebi Bozkurt, "Mescid-i Nebevî” TDVIAA, İstanbul 2003, XXVIII, 283.

56 Eyüp Sabri Paşa, Mir'at-i Medine, İstanbul 1304, s.718.

57 İbrahim Ateş, "Mescid-i Nebevî’nin Yapıldığı Günden Bu Yana Geçirdiği Genişletme Girişimleri”, Vakıflar Dergisi, XXIV, Ankara 1974, s. 9. 
yerlerine çeşmeler yapılmıştır. Bu dönemde de Medine'de ziyaretçilerin ihtiyaçlarını karşılayacak hastane, ribat ve hamam inşa edilmiştir ${ }^{58}$.

Sultan III. Murat Harem-i Şerif'de olduğu gibi Mescid-i Nebevî'de de oldukça önemli imar girişimlerinde bulunmuştur. Sultan III. Murad'ın, saltanatını Mekke ve Medine'nin imarına adadığını söylemek abartı değildir. Mesela Mısır Beylerbeyine gönderilen 29 Eylül 1578 tarihli bir fermanda böyle bir faaliyetin izlerini bulmaktayız. Söz konusu fermanda yıkılmaya yüz tutmuş Mescid-i Nebevî'nin şark duvarlarının derhal tamir edilmesini emretmektedir. Medine kadısından gelen yazıya istinaden bu tamir için gerekli olan miktarın 4000 flori olduğunu bildirerek bunun derhal Mısır'dan ödenmesini istemiştir. Bu normal emirde dikkat çeken husus ise bu tamiratın geciktirilmesi halinde pek çok ev ve rıbatın ve buralarda yaşayan Müslümanların zarar göreceğinin beyan edilerek, işin öneminin vurgulanmasıdır. Aynı emirde Mısır'dan Yenbu limanına gönderilen zahirenin yağmurdan zarar görmemesi için harap durumdaki depoların tamir edilmesi talep edilmiştir ${ }^{59}$. Bu taleplerin sadece Mescid-i Nebevî ile sınırlı olmaması Sultanın bölgede hayatı kolaylaştırmaya dönük bir siyasetinin olduğunu göstermektedir.

1586 senesinde Mescid-i Nebevî’nin Babü’n-Nisa duvarı yıkılmaya yüz tutmuş ve tamiri zorunlu hale gelmişti. Bu doğrultuda Medine'ye İstanbul'dan ustalar ve inşaat malzemeleri yollandı. Mezkur duvar yıkılarak yeni bir duvar inşa edildi ${ }^{60}$. Ravza' da hafızlar için ayrılmış alanda genişletme yapılarak iki saf daha ilave edildi. Ayrıca Babü's-Selam tarafında da bir Darü'l-Hadis inşa edilmiştir. Yapılan yeni duvara konulmak üzere İstanbul'dan üzerine tarih düşülmüş ve naatlar yazılmış bir mermer yollandı. Bu mermer kitabe duvarın münasip bir yerine törenle konuldu. Aynı düzenlemeler sırasında bazı perde ve örtüler M1sır'dan getirilmiş, ancak Hz. Peygamberin türbesinin örtüsü İstanbul'da dokutularak Medine'ye gönderilmiştir. Ayrıca Mescid-i Nebevî'nin minberi yeniden elden geçirilmiştir. Bunun için gerekli mermerin de Mısır'dan getirtildiği kayıtlara geçmiştir ${ }^{61}$.

Mescid-i Nebevîde Osmanlı Devleti tarafindan ilk kubbe Sultan III. Murad zamanında yapıldı. Mescid-i Nebevînin arka tarafinda bulunan üç sıra çatı yıkılmaya yüz tutmuş ve tehlike arz etmeye başlamıştı. Bu durum aynı zamanda çirkin de bir görüntü oluşturuyordu. Hadise padişaha arz edilince padişah da M1sır beylerbeyini bu işle görevlendirdi. Beylerbeyi de vakit kaybetmeden gerekli usta ve malzemeleri Medine’ye gönderdi. Görevli ustalar ulemanın da görüşünü

58 Eyüp Sabri Paşa, a.g.e. s.718.

59 BOA, MD 35/ 749.

60 Eyüp Sabri Paşa, a.g.e. s.724.

61 BOA, MD 36/ 909.; Suraiya Faroqhi, a.g.e., s.134 
alarak çatıları yıkarak yerlerine üç sıra kubbe inşa etti. Bununla birlikte bu kubbelere bitişik olan üç sıra ahşap kubbeler kargire dönüştürüldü. İnşa edilen üç sıra kubbenin her sırası dokuz kubbeden oluşuyordu. Bu kubbelerden Hücre-i Saadet hizasına gelen kubbelere yazın Mescid-i Nebevînin soğutulması için baca inşa edildi $^{62}$. Bu faaliyetlerin 1590 ile 1594 yılları arasında tamamlandığ bilinmektedir. Bütün bunlar yapılırken, Mescid-i Nebevînin iç tefrişatı ve aydınlatılması için gerekli malzemelerin de Mısır'dan gönderilmesi için sıkı emirler verildiği belgelerden anlaşılmaktadır.

Sultan III. Mehmet (1595-1603)'in kisa saltanat yıllarında Misır vergisinin bir kısmı Medine'de yarım kalan imar faaliyetlerine tahsis edilmiştir. III. Mehmet zamanında Mescid-i Nebevî' de imar anlamında ciddi değişiklik olmamakla beraber buranın temel ihtiyaçlarından olan halı ve örtüler yenilenmiştir ${ }^{63}$. On yedinci yüzyılın başında Sultan I. Ahmet (1603-1617) zamanında Ravza-i Mutahhara ile bazı kabirlerin örtüleri tekrar yenilenmiştir. Yine bu devirde Hücre-i Saadet'e konulmak üzere gümüş bir levha yollanmıştır. Ayrıca Babu'r-rahme yanında bir çeşme ile Hanbeli mezhebine bağlı talebelerin kalması için bir medrese inşa edilmiştir ${ }^{64}$.

\section{b) Medine'de Çevre Düzenlemeleri ve Şehrin İmarı}

Mescid-i Nebevî Medine'deki imar faaliyetleri için bir merkez oluşturuyordu. Hz. Peygamberin kabri ve mescidinden başlatılan imar dışarıya da taşarak bütün şehre yayılıyordu. Buradaki inşaat malzemeleri ya Mısır'dan veya Misır yolu ile başka taraflardan getirilmekteydi. Gerekli bütçe merkezden, Mısır bütçesinden veya vakıflardan karşılanmaktaydı. Ustalar, taş işçileri, demirciler de dışardan getirilerek tecrübelerini Medine'ye taşıyorlardı.

Medine'nin bir parçası olan Medine kalesi de şehirde ilk onarılan yerlerden biri olmuştur. Ancak zaman içinde kaleye bitişik düzensiz bir şekilde evler yapıldığg anlaşılmaktadır. Bu evler zamanla kale duvarlarına zarar vermeye başlamıştı. 1568 yılında Medine kadısı ile Şeyhulharem uyarılarak bundan böyle kaleye bitişik evler yapılmasının engellenmesi ve o güne kadar yapılanların temizlenmesi istenmiştir. Ayrıca yapılaşmayı engellemek için de kale civarında kerpiç kesiminin yasaklanmas ${ }^{65}$ merkezin bu kadar uzaktaki bir yerin şehirleşmesini iyi takip ettiğini göstermektedir. Bu da bize genel olarak şehrin geneline bakıldığını ve Osmanlı idarecilerinde bir şehircilik fikrinin olduğunu göstermektedir. Tabii ki kale sadece askeri bir görev görmemekteydi. İçinde genellikle görevlilerin yaşa-

62 Eyüp Sabri Paşa, a.g.e. s.726.

63 A.g.e. s.733.

64 A.g.e. s.738.

65 BOA, MD 7/1390.; An'am Mohammed Osman Elkabashi, Osmanlı Medinesi: XVI. YY'da Mukaddes Bir Şehrin İdarî, Sosoyal ve Ekonomk Yapısı, İstanbul Üniversitesi yayımlanmamış doktora tezi, 2006, s. 29. 
dığı bir de mahalle oluşmuştu. 1590 yılındaki bir kayıtta kale içinde 17 ailenin yaşadığı belirtilirken ${ }^{66}$ Evliya Çelebi yaklaşık yüz yıl sonra bu sayının 120 haneye çıktığını yazacaktır.

Hazreti Peygamberden beri Medine'nin ana yerleşim yerini Harem mahallesi oluşturmaktaydı. Yaklaşık $22 \mathrm{~km}$.lik bir daireyi oluşturan bu bölgenin muhtelif yerlerinde mescitler, medreseler, kütüphane, tekke, zaviye ve rıbatlar yer almaktaydı. Osmanlılar zamanında da şehrin çekirdeğini bu mahalle oluşturmuştur. Yerli halk ve mücavirlerin yaşadığı Harem mahallesinin, sayısı tam olarak bilinmese de yoğun bir nüfusa sahip olduğu tahmin edilebilir. 1580 tarihli bir kayıtta Medine'ye gönderilen buğdaydan 8 bin kişinin istifade ettiği söylendiğine göre nüfusun bundan fazla olduğu anlaşılmaktadır. Nitekim 1590 yılına ait bir başka sürre kaydında Medine nüfusu on bin olarak verilmektedir ki, bu örnekler şehir nüfusunun 16. yüzyıl boyunca sürekli artış gösterdiğini ortaya koymaktadır ${ }^{67}$.

Sultan III. Murad döneminde sürre hak sahiplerini tespit etmek için yapılan bir tahrire göre; Medine'de 6 binden fazla kişiye sürre verildiği anlaşılmaktadır. Şehrin nüfusunun bundan fazla olduğu muhakkaktır. Aynı şekilde sürreden istifade edenlerin ikamet yerleri de kaydedilmiştir. 1596 yılına ait olan bu sayımda 4350 kişinin muhtelif mahallelerdeki evlerde, 769 kişinin rıbatların eski odalarında, 692 kişinin rıbatların yeni yapılan odalarında, 42 kişinin çeşitli zaviyelerde oturdukları kaydedilmiştir. Sürre alan beş yüzden fazla kişinin ise nerede oturdukları belirtilmemiştir ${ }^{68}$. Bu kayıtlar bize Medine şehrinin genel yapısı ve demografisi hakkında önemli bilgiler vermektedir.

Dünyanın her tarafından gelen Müslümanların oluşturduğu Medine toplumu aynı zamanda kültürel çeşitliliği de temsil ediyordu. Sosyal etkileşim hızlı idi ve gelen mücavirler hemen Medine toplumuna uyum sağlıyorlardı. Bu anlamda Mescid-i Nebevî başta olmak üzere diğer mescitler adeta birer okul vazifesi görmekteydi. Bu yüzden var olan mekanların imar ve tamiri ve yenilerinin ilavesi dini bir görev addediliyordu.

Hz. Peygamber'in yaptırdığ 1 ilk mescit olan Kuba mescidinin Osmanlılardan önce değişik tarihlerde tamir edildiği bilinmektedir. Sultan III. Murat'ın saltanatının son yıllarında içi yeniden tefriş edilmiş ve kandiller ile aydınlatılmış ve görevliler tayin edilmiştir. Hatta etrafına da bir kısım aileleri yerleştirerek mescidin etrafının da daima mamur olmasını sağlamıştır. Aynı şekilde, 1596 yılında Hz. Ebubekir Mescidine imam, müezzin, vekkad (kandil yakıc1) bir ferraş ile bir bevvabın (kapıcı) tayin edilmesi dikkatleri çekmektedir. Aynı sene Hz. Ali mescidinin de tamir edildiği kayıtlarda yer almaktadır ${ }^{69}$.

66 Topkapı Sarayı Müzesi Arşivi, SD 1316.

67 Elkabashi, a.g.tez. s. 32-33.

68 Aynı yer.

69 Topkapı Sarayı Müzesi Arşivi, SD 1209/2. 
On altıncı yüzyılda Medine'deki imar faaliyetlerinin bir başka yönü de inşa edilen medreselerdir. Medine'de Osmanlıların ilk inşa ettikleri medrese Kanuni Sultan Süleyman'ın veziri Rüstem Paşa'nın medresesidir. 1569 yılında Medine kadısına gönderilen bir hükümde bu medreseden söz edilerek, burada talebelerden başkasının yani Medine'ye gelen ziyaretçilerin barındırılmaması istenmektedir $^{70}$. Bu durum söz konusu medresenin bu tarihten önce inşa edildiğini ve o tarihlerde faal olduğunu göstermektedir. Aynı şekilde Sultan III. Murat'ın saltanat yıllarında yine kendi hesabından bir medrese inşa ettirdiği ve bunun en azından 17. yüzyılın başına kadar hizmet verdiği kaynaklarda geçmektedir ${ }^{71}$. Kısa saltanatı süresinde III. Mehmet'in de Medine'de bir medrese yaptırdığı bilinmekle birlikte kayıtlarda hakkında fazla bilgi yoktur. 1596 yılı kayıtlarında sözü edilen bir diğer medrese ise Mehmet Ağa Medresesidir. Aynı yılın sürre defterindeki kayıtlardan anlaşıldığına göre bu medrese öğrencilerinden yedisine sürreden pay verilmiştir ${ }^{72}$.

Aslında her yıl yenilenen sürre defterleri bize nüfus bilgilerinin yanı sıra burada yaşayan ahalinin sosyal statüleri ve milliyetleri hakkında bilgi verdiği gibi, medreseler hakkında da yadsınmayacak veriler sunmaktadır. Ancak bu kayıtlardan medreselerin inşa tarihleri hakkında bilgi sahibi olamamaktayız. Mesela Resmiye medresesi ile Kubbe-i İslam medreseleri bu kabildendir. Her ikisi de 1596-1600 tarihli kayıtlarda geçmekte ama kim tarafindan ve ne zaman yapıldıkları yazılmamaktadır. Ancak 16. yüzyılın sonunda Medine medreselerinde en az on beş müderrisin var olduğu dikkate alınırsa, Medine'deki eğitim faaliyetlerinin ne denli yoğun olduğu anlaşılmaktadır ${ }^{73}$. Bu medreselerin hemen tamamında yüksek dini ilimler tahsil edilmekteydi. Ayrıca16. yüzyılda daha ziyade çocukların eğitimi için Medine'de on mektebin hizmet verdiğini bilmekteyiz ki, bunlardan Hümayun adını taşıyan mektep padişah tarafindan; birisi de Sultan III. Murad'ın annesi Safiye Sultan tarafından yaptırılmıştır. Bu mekteplerin her birinde fakîh adı verilen en az bir muallim/öğretici bulunmaktaydı. Öğrenci sayılarını tam olarak bilmiyoruz ama bazı mekteplerdeki öğrenci sayılarının 50-60 olarak belirtilmesi, genel olarak bir fikir sahibi olmamıza imkan vermektedir. Bu sınırlı kayıtlar esasında 16. yüzyılda Medine'de Mescid-i Nebevî dışındaki eğitim hayatı hakkında önemli ipuçları sunmaktadır. Bütün bu mekteplerin masrafları, öğrencilere yapılan harcamalar vakıflardan veya Sultanların tahsisatlarından karşılanmaktaydı.

Genellikle fakir fukaraya, medrese öğrencilerine, yolculara, kimsesizlere günlük olarak yemek dağıtmayı amaçlayan imaretler Osmanlı şehirlerinde yaygın

70 BOA, $M D$ 3/1136.

71 Elkabashi, a.g.tez, s. 46.

72 Topkapı Sarayı Müzesi Arşivi, SD, 1214.

73 Elkabashi çalışmasında bu müderrislerin isimlerini vermektedir: Elkabashi, a.g.tez, s. 48. 
bir şekilde bulunmaktaydı. Bu uygulama aynen Medine'ye taşınarak, buradaki ihtiyaç sahiplerinin de ihtiyaçlarının giderilmesi sağlanmıştır. Nitekim Osmanlı padişahları tarafından Medine'de açılan en eski imaret, Kanuni Sultan Süleyman zamanına aittir. Ne zaman inşa edildiği tam olarak bilinmemekle birlikte 1582 y1lında hâlâ hizmet vermeye devam ettiği bir yazışmadan anlaşılmaktadır ${ }^{74}$. Diğer taraftan Hürrem Sultan adına Medine'de inşa edilen imaretin özelliği ise şehir surlarının dışında olmasıydı. Böylece şehrin merkezine ulaşamayan ihtiyaç sahipleri bu imaretten istifade edebilmekteydiler. Kayıtlarda bu imaretin ortasında minareli bir mescidin de bulunduğu yazılıdır. Her gün fakirlere çorba ve ekmek dağıtılan bu imaretin mutfak kazanlarının yenilenmesi, 1575 yılında birçok yazışmaya konu olmuştur. 5 Kazan İstanbul'da imal edilip Misır üzerinden Medine’ye gönderilmiştir. Küçük olmadığı düşünülen kazan sayısı bize imaretin büyüklüğü hakkında da bir fikir vermektedir ${ }^{75} .1578$ tarihli bir başka yazışmada ise aynı tarihlerde hizmet vermekte olan Sultan III. Murad imaretinden söz edilmektedir ${ }^{76}$. Orta büyüklükte olduğu anlaşılan bu imaretin görevlilerine ve aşçılarına günlük birer altın verilmesi zengin bir imaret olduğunu göstermektedir.

1590 yıllarında Medine'de genel bir imar faaliyeti sürdürülmekteydi. Bu çerçevede III. Murad adına yeni bir imaretin daha yapıldığı anlaşılmaktadır. Söz konusu imarette bir ambarın, bir mutfağın ve bir kaç deponun bulunması büyüklüğüne işaret etmektedir. İmaret genel olarak fakir fukaraya hizmet etmesine rağmen Pazartesi ve Perşembe günleri burada pişirilen yemekler bütün Medine ahalisine dağıtılmaktaydı. Mısır'dan satın alınan bazı bağ ve bahçelerin gelirleri bu imarete vakfedilmiştir. Bazı kayıtlara göre her yıl bu vakıflardan 25 bin altın gönderiliyordu. Sadece bu meblağın Medine'de tedavüle girmesi bile önemli bir ekonomik canlılık sağladığında kuşku yoktur ${ }^{77}$. Aslında imaretler bunlardan ibaret değildi. Sınırlı da olsa bazı kaynaklarda Hz. Peygamber adına hizmet veren bir imaret ile Sultan III. Mehmed'e ait başka bir imaretten de söz edilmektedir ${ }^{78}$.

Medine'de daha Kanuni'den beri bir hastahanenin var olduğu bilgisine sahibiz. Fakat erken tarihli kayıtlar bu konuda bize yeterli bilgiler vermemektedir. Elimizde hastahaneye dair bir kayıt 1568 tarihini taşımaktadır. Bu da II. Selim'in saltanat yıllarının başına rastlamaktadır ${ }^{79}$. Ancak hastahanenin babası ya da kendisi tarafından mı yaptırıldığına dair bir işaret bulunamamaktadır. 


\section{c) Yaşama Alanlarına ve Ziyaretçilerin İhtiyaçlarına Dönük Faaliyetler}

Medine'ye gelenlerin kalması için değişik dönemlerde ribatlar inşa edilmiştir Bunlar daha ziyade hayırseverler tarafından kurulan barınma mekânlarıdır. Bunların inşası, burada yapılan harcamalar ve kalanların ihtiyaçlarının görülmesi şehrin ekonomisini canlı tutmaktaydı. 1565-1566 yıllarına ait yazışmalarda Kanuni Sultan Süleyman'ın eski ribatların tamir edilmesi ve yenilerinin yapılması için emir verdiği görülmektedir. Mısır beylerbeyine yazılan emirde bu iş için Medine kadısına bin sikke altın gönderilmesi emredilmiştir. Benzeri emirler Sultan III. Murad döneminde de tekrarlanmaktadır. Bu da ribat tamiri ve inşa faaliyetinin devam ettiğine delalet etmektedir. 1585 yılında Medine'de mevcut ribatların tamirine karar verilmiştir. Bu konuda Medine kadısı ve şeyhulhareminden gelen keşfe istinaden Mısır beylerbeyi ve defterdarına yazılan bir hükümde; bin sikke altına ihtiyaç duyulduğu belirtilmiş ve bu meblağın Mısır hazinesinden karşılanması emredilmiştir. Ayrıca önemine binaen işin geciktirilmemesi de özellikle vurgulanmıştır ${ }^{80}$.

On altıncı yüzyılın başında, Osmanlılardan önceki döneme ait Medine'de en az on tane ribatın ismi ve faaliyeti bilinmektedir. Ancak 16. yüzyılın özellikle ikinci yarısında Medine'de yaşanan gelişmelere ve ziyaretçilerin artmasına paralel olarak bu ribatların sayısı yüzlere varmıştır. Sur içinde yapılan büyük küçük binalardan oluşan bu ribatlarda kalanların her birine bir oda tahsis edilmekteydi. Ribatlar oda sayısına göre küçük, orta ve büyük olmak üzere üç çeşit idi. Sultan III. Murat da Medine'de Kuba Mescidi civarında 1577-1578 tarihlerinde 40 odalı bir ribat inşa ettirdiği kayıtlarda görülmektedir ${ }^{81}$. Şehrin değişik yerlerindeki bu ribatlarda hem kadın ve hem erkeklere oda tahsis edildiği gibi sadece kadınlar için de ribatlar mevcuttu. Bu ribatların ve kalanların isimlerini 16. yüzyılın sonlarına doğru düzenlenmiş sürre defterlerinde görmek mümkündür ${ }^{82}$. Bu ribatlar sadece bir barınma yeri değildi. Ribatlarda Şeyh, Müderris gibi görevlilerin varlığından aynı zamanda eğitim faaliyetlerinde de bulundukları anlaşılmaktadır. Aslında bu ribatların önemli bir bölümünün Medine'deki tasavvufi hayatı da temsil ettiğini söylemek abartı olmayacaktır. Zira bunların en azından bir bölümünün çeşitli yerlerden gelerek burada yaşayan tasavvuf ehlinin kaldıkları ve kendi tarikatlarına mensup müritlerini de o mekanlara celp ettikleri tahmininde bulunmak mümkündür. Onaltıncı yüzyılda Medine'de ribatlardan başka zaviyeler de hizmet sunmaktaydı. Aynı yüzyılın ikinci yarısındaki kayıtlarda sekiz adet zaviyenin ismi geçmektedir ki, bunlardan bir tanesi Kanuni Sultan Süleyman'ın eşi Hürrem Sultan'ın adını taşımaktayd $1^{83}$. Çeşitli yerlerden gelen ziyaretçilere konaklama imkanı veren bu zaviyeler aynı zamanda tasavvufi ilimlerin de öğretildiği mekanlardı.

80 BOA, MD 6/91, 92.; 58/ 706.

81 Topkapı Sarayı Müzesi Arşivi SD, 5634/1; BOA, $M D, 70 / 33$.

82 Bu ribatların sürre kayıtlarından çıkarılmış bir listesi için bakınız: Elkabashi, a.g.tez, s.65-69.

83 Topkapı Sarayı Müzesi Arşivi SD 1214; Elkabashi, a.g.tez, s. 78. 
Daha önce de belirttiğimiz gibi vakıflar Haremeyn'de ciddi bir iktisadi hareketlilik meydana getirmekteydi. Şimdilik eldeki bazı kayıtlara göre 16. yüzyılın sonlarında bir kısmı Sultanların veya yakınlarının olmak üzere Medine'de faaliyet gösteren on bir vakıf bulunmaktaydı. Bunların bir bölümü akarı olan vakıflar iken bir bölümü de para vakıflarıydı. Tabii olarak hem akardan ve hem de para vakıflarından toplanan gelirler vakıfta belirlenen şartlara uygun olarak harcanırken; dolaylı olarak da Medine'nin imarına ciddi katkılar sağlamaktaydı. Zira vakıfların gelirleri şehirde iktisadi bir hareketlilik, dolayısıyla bir imar hareketi sağlamakta ve tahsis edildikleri alanlara ihtiyaç anında harcanabilen cari bir bütçe özelliği de taşımaktaydı.

Osmanlı Sultanları Mekke'de olduğu gibi, Medine'nin su ihtiyacı ile de yakından ilgilenmişlerdir. Aynu'l-Zerka suyunun isalesi ve Medine'de ihtiyaç duyulan bir kaç yerde çeşme yapımına dair belgeler bulunması bu ilgiye delalet etmektedir. Mesela 1580 yılında Medine kadisına yazılan bir emirde, Mescid-i Nebevî’nin önüne bir çeşmenin inşası emredilmekteydi. 1586 ve 1593 tarihli fermanlarda da buna dair emirlerin var olması, hem ihtiyacın devam ettiğini ve hem de bu konuda bir şeyler yapıldığını göstermektedir ${ }^{84}$. Medine Şehrinin ana su kaynağı Aynu'l-Zerka olduğu için devlet bu suyun şehre isalesine büyük önem veriyordu. Nitekim hem Kanuni Sultan Süleyman ve hem de oğlu II. Selim Medine suları ile ilgilenmiş ve birçok su kaynağ 1 Aynu'l Zerka suyuna katılmıştır ${ }^{85}$. Ancak III. Murad zamanında meydana gelen bir sel tamir edilen bu su yollarını tahrip etmiştir. Nitekim o da selefleri gibi Medine'deki imar faaliyetleri arasına su yollarının yeniden tamirini de alarak şehrin su sıkıntısını gidermiştir. Tamirden sonra da kanalların temizliği ve suyun sürekli şehre akıtılması işinde 15901596 yılları arasında 10 ile 20 kişi arasında değişen görevliler çalıştırılmıştır. $\mathrm{Bu}$ çalışanların başında bir nazır bulunmakta ve bu görevlilerin tamamı her yıl Medine'ye gönderilen sürreden pay almaktaydılar ${ }^{86}$. Aynı şekilde Medine'de hamamlar inşa edilmiş ve halkın hizmetine sunulmuştur. Bunun dışında Bakî mezarlığı için bazı düzenlemeler düşünülmüş ise de ne kadarının hayata geçirildiği konusunda yeterli bilgimiz bulunmamaktadır.

\section{d) Medine'de Meslekî ve İktisadî Hayatın Gelişmesi}

16. yüzy1lda Mescid-i Nebevî’nin ve Medine şehrinin idaresi, düzenin ve güvenliğin sağlanması için birçok resmi görevliler tayin edilmiştir. Bunlar uzun yıllar burada kalarak Şehrin gelişmesine katkıda bulundular. Bunun dışında dünyanın çeşitli yerlerinden buraya gelen alimler de şehri cazibe merkezi yapıyordu. Medine şehrinin başka bir Müslüman şehirde rastlanmayacak bir özelliği daha

84 Suraiya Faroqhi, a.g.e., s. 136; Elkabashi, a.g.tez s. 77.

85 Eyüp Sabrı Paşa, a.g.e., s. 720.

86 BOA, $M D 31 / 856 ; 33 ; 127$. 
vardı. Onaltıncı yüzyılda Medine'de "fakîh kadınlar" diye bir grup bulunmaktaydı. Bunlar Osmanlı sürre defterlerine bağımsız bir şekilde kaydedildiklerine göre, fiilen kadınlara dini öğreten bir grup oldukları anlaşılmaktadır. 1600 tarihli sürre defterinde kayıtlı kadınların sayısı 86 kişidir ki, o gün için azımsanmayacak bir rakamdır ${ }^{87}$.

Resmi görevlilerin dışında Medine'de bulunan bazı meslek erbabı da kayıtlara geçmiştir. 1583-1584 tarihli kayıtlarda Medine'de firınc1, değirmenci, tatlıcı ve oduncudan bahsedilirken; 1590 yılı kayıtlarında bu meslekleri yapanlar bir kaç kat artmıştır ki, bu da şehrin geliştiğini göstermektedir. Bunda şüphesiz III. Murat'ın başlattığı imar faaliyetlerinin önemli katkısı olmuştur. Nitekim 1590larda marangozluk ve kantarcı olarak iki meslek türünün daha ortaya çıkmasının şehirde başlatılan inşaat faaliyetleri ve ziraatın gelişmesi ile alakalı olması gerektir. Zira kantarcılar daha ziyade zirai ürünlerin ölçü ve tartısını yapıyorlardı. Medine esasında zirai bir toplum idi, ancak imarın artmasına paralel olarak nüfusun artması da üretilen hububat ve özellikle hurmanın da önemini arttırdığı varsayılabilir. Hatta sadece hurma için bir çarşının daha o tarihlerde oluştuğu bilinmektedir. On altıncı yüzyılın sonunda Medine'de kayıtlara geçen 14 firınc1, 13 değirmenci, 10 oduncu, 9 tatlıc1, 2 kantarc1 ve 1 marangoz bulunmaktadır ${ }^{88}$. Bu mesleklerin dışında hayvancılık ile uğraşan ve yağ üreten yağcılar da kayıtlara geçmiştir. Nitekim 1596 yılında yağcılık işinde çalışan 18 meslek sahibinin olduğuna bakılırsa şehrin etrafinda hayvancılığın da bir hayli geliştiği tahmini yapılabilir. Aynı tarihlerde Medine'de sadece bir kasabın olması, tüketicilerin canlı hayvan alarak kesimlerini kendilerinin yaptıkları şeklinde yorumlanabilir. Zaten kaynaklar bir hayvan pazarından da söz etmektedirler. Hurma pazarının yanı sıra şehirde ot, odun ve kömür pazarı ile hububat ve sebze pazarının da olduğu bilinmektedir.

Bu yüzyıllarda Medine'de ticaret ile ilgili mesleklerin de kayıtlara geçtiğini görmekteyiz. Bu kadar gelişmiş bir toplumda her türlü ticaret ehlinin olduğu muhakkaktır. Ancak anlaşılan o tarihte şehirde iki gözde meslek bulunmaktadır ve bunlar da kayıtlara geçmiştir. Birincisi ipek ticareti idi. Medine'ye ipek İstanbul, Misır ve Hindistan üzerinden geliyordu. 1584 yılında şehirde bu ticaret ile uğraşan sadece dört kişi var iken, 1596 yılında bu sayı 13'e çıkmıştır. İkincisi de kuyumculuktur. Medine'de eski bir meslek olan kuyumculuk bu tarihlerde gelişme göstermiştir. 1590 yılında Medine'de bu mesleği icra eden sekiz kişi bulunmaktadır ${ }^{89}$. Genel olarak kaynaklar on altıncı yüzyılın sonu ve 17. yüzyılın başında Medine'de ticaretin arttı̆̆ını kaydederler. Zaten verdiğimiz örnekler de bunu kanıtlamaktadır. Ticaret kervanları eskiden olduğu gibi yine Şam-Medine arasında gelip giderdi. Medine'ye ulaşan mallar Hicaz'ın her tarafına hatta gelen

87 Elkabashi, a.g.tez., s. 116.

88 Topkapı Sarayı Müzesi Arşivi SD, 1209; 1212; 1316.

89 Elkabashi, a.g.tez s. 119. 
ziyaretçiler aracılığı ile dünyaya dağılırdı. Ticaretin artmasında yol emniyetinin olması ile Medine halkının alım gücünün artmasının sebep olduğu söylenebilir. Bunda her y1l merkezden gönderilen sürrenin de önemli katkısının olduğu kabul edilmelidir. Mesela 1584 ile 1589 yılları arasında Medine'ye gönderilen sürre 31.4 kat artmıştır $^{90}$. Kuşkusuz alım gücünün artmasında daha önce zikredilen Medine'deki vakıfların faaliyetleri ile Medine dışında olup doğrudan sürre gönderen vakıfların de katkısı olmuştur. Elkabashi çalışmasında bu dönemde sadece Şam, Gazze, Nablus ve Trablus vakıflarından Medine'ye gönderilen sürrenin bir dökümünü yapmıştır. Buna göre toplam meblağ 114205 sikkeye ulaşmaktadır ${ }^{91}$.

On altıncı yüzyılın ikinci yarısında Medine'de imarın artması, ziraat ve ticaretin gelişmesi nüfusun da artmasına sebep olmuştur. Kuşkusuz bunda en büyük pay mücavir sıfatı ile Medine'ye yerleşenlerdir. Mücavirlerin yerleşme sebebi hiç kuşkusuz Hz. Peygambere komşu olma arzusudur. Bu yüzden olumsuz hayat şartları olsa da mücavirleri engellememektedir. Ancak şehrin gelişmesi, ticaretin artması ve halkın yaşantısının kolay olması mücavirliği de özendiren bir husus olduğu muhakkaktır. Bunu mücavirlerin geldiği ülkelere göre yapılan tasnifte görmek mümkündür. On altınc1 yüzyılın sonunda Medine'de Yemenliler, Hintliler, Acemler, Mısırlılar, Mağripliler, Şam ve Halebliler, Bağdatlılar, Kürtler, Doğu Afrika'dan Cebertîler, Afrika'dan gelen Tekrürler ile Anadolu'dan giden Türkler bulunmaktayd $1^{92}$. Bunlar arasında en yüksek sayı Türkler iken ikinci sıradakiler Yemenliler idi. Bütün bu gruplar, mücavir olmalarının yanında başta eğitim işleri olmak üzere, sahip oldukları meslekleri ile de şehre ciddi katkı verdiklerinde kuşku yoktur.

90 Topkapı Sarayı Müzesi Arşivi SD,1209; 1215; Ayrıca bir değerlendirme için bak: Elkabashi, a.g.tez s. 119.

91 A.g.tez s. 157.

92 Bu gurupları her yıl Medine’ye gönderilen sürre defterlerinden takip etmek mümkündür. 


\section{Sonuç}

Haremeyn Osmanlı idaresine "teyemmünen ve teberrüken" girmiştir. Bütün Osmanlı sultanları bunun farkındadır. Osmanlı Sultanları İslam'ın bu iki kutsal şehrine hizmet etmeyi dini bir görev bilmiş ve daima bu doğrultuda hareket etmişlerdir. Ancak burası da idareler altında olan oldukça hareketli bir bölge ve her yıl dünyanın birçok yerinden Müslüman ziyaretçilerin geldiği bir nokta idi. Haremeyn işleri ile ilgilenerek Osmanlı Sultanları aynı zamanda Müslümanlar nezdindeki hilafet sıfatlarını ve iktidarlarını da meşrulaştırıyorlardı. Bu yüzden bölgenin imarı önem arz ediyordu. Osmanlı Sultanlarının on altıncı yüzyılın ilk çeyreğinde Haremeyn'de başlattıkları imar faaliyetlerinin daima bir süreklilik gösterdiği belgelerden ve maddi kültür kalıntılarından takip edilebilmektedir. Haremeyn'e yapılan hizmetler hızla gelişme gösterirken bu mekânlara kutsiyet kazandıran Kâbe ve Mescid-i Nebevî genişletildiği gibi şehirler de gelişmiş ve nüfus çoğalmıştır. Osmanlılar her iki şehri de hac ve hazreti peygamberin ziyaretgâhı, dini birer merkez olarak görmüş olsalar da, yaptıkları yatırımlar Haremeyn'in maddi olarak gelişmesine de vesile oldu. Bölgeye yapılan bu yatırımlar, bir taraftan hilafet siyasetinin gereği, diğer taraftan da doğrudan devletin idaresindeki mülkün imarı yani iktidarın göstergesi olarak değerlendirilmelidir. 


\section{Kaynakça}

\section{Arşiv Kaynakları}

Başbakanlık Osmanlı Arşivi (BOA), Mühimme Defterleri (MD) 3,5, 6, 7, 10, $12,21,29,31,35,36,47,48,64,67,70$.

Başbakanlık Osmanlı Arşivi Evkaf Defterleri, (EV. HMK.) 192, 2422.

Topkap1 Sarayı Müzesi Arşivi, Sürre Defterleri, (SD) 1209, 1212, 1214, $1215,1316$.

\section{Kaynak Eserler ve Araştırmalar}

Abdurrahman Hibrî, "Menâsik-i Mesâlik", İ.Ü..Edebiyat Fakültesi Tarih Enstitüsü Dergisi, neşr. Sevim İlgürel, say1 6, Ekim 1975.

Âşık Paşazâde, Osmanoğulları Tarihi, Tevârih-i Âl-i Osman, haz. Kemal Yavuz, M. A. Yekta Saraç, 2. bs., İstanbul, 2010.

Ateş, İbrahim, "Mescid-i Nebevî’nin Yapıldığg Günden Bu Yana Geçirdiği Genişletme Girişimleri”, Vakıflar Dergisi, XXIV, Ankara, 1974.

Aydeniz, Tuğba, “Osmanlı Devleti'nde Mekke'nin Yönetimi (1517-1617)”, (Yayınlanmamış Doktora Tezi), Marmara Üniversitesi Türkiyat Araştırmaları Enstitüsü, İstanbul, 2010.

Aydın, Sabit, “Osmanlı Döneminde Medine'de Yapılan Tarihi Eserler”, (Yayımlanmamış Yüksek Lisans Tezi), Erciyes Üniversitesi Sosyal Bilimler Enstitüsü, Erzincan, 2007.

Bozkurt, Nebi, "Mescid-i Nebevî” Türkiye Diyanet Vakfi İslam Ansiklopedisi (TDVIA), XXVIII, İstanbul, 2003.

Buzpınar, Ş. Tufan-Küçükaşçi, Mustafa S., "Haremeyn”, TDVIA, XVI.

Celâlzade Mustafa, Selim-Nâme, haz. Ahmet Uğur, Mustafa Çuhadar, Ankara, 1990.

Doğan, Faruk, "18 ve 19. Yüzy1llarda Şam-Medine Hac Yolu Güvenliği: Cerde Başbuğluğu”, Tarih Okulu Dergisi, yıl 6, sayı XV, Eylül 2013.

Elkabashi, An'am Mohammed Osman, “Osmanlı Medine'si: XVI. YY'da Mukaddes Bir Şehrin İdarî, Sosyal ve Ekonomik Yapısı”, (Yayımlanmamış Yüksek Lisans Tezi), İstanbul Üniversitesi, İstanbul, 2006.

Emecen, Feridun M., "Hicaz'da Osmanlı Hâkimiyetinin Tesisi ve Ebu Numey”, Tarih Enstitüsü Dergisi (TED), sayı 14, 1994.

, Imparatorluk Çă̆ı'nın Osmanlı Sultanları I, İstanbul, 2011.

Eraslan, Sadık, "Osmanlıların Haremeyn-i Şerifeyn Hizmetleri” Diyanet İlmi Dergi, c. 35, sayı 1, Ocak-Şubat-Mart 1999. 
Evliya Çelebi, Seyahatnâme, c. 9, İstanbul, 1935.

Eyüp Sabri Paşa, Mir'at-i Medine, İstanbul, 1304.

Faroqhi, Suraiya, Hacılar ve Sultanlar, Osmanlı Döneminde Hac 1517-1638, İstanbul, 1995.

Feridun Ahmed Bey, Münşeâtü’s-Selâtîn, c. I, İstanbul, 1264-1274/18481858.

Güler, Mustafa, Osmanlı Devleti'nde Haremeyn Vakıfları (XV.-XVII. Yüzyıllar), İstanbul, 2002.

İbn İyas, Bedâyi'u'z-Zuhûr fì Vekayi 'i'd-Duhûr, (Yavuz'un Mısır'1 Fethi ve Mısır'da Osmanlı İdaresi), çev. Ramazan Şeşen, İstanbul, 2016.

İpşirli, Mehmet "Cerde”, TDVİA, VII, 1993.

Kudbeddin Nehrevalî, el I'lâm bi A 'lâmi Beytullahi'l-Harem, II, Göttingen, 1858.

Kurşun, Zekeriya, "Hicaz (Osmanlı Dönemi)”, TDVİA, XVII, 1998.

Küçükaşçı, Mustafa S., Abbasilerden Osmanlılara Mekke-Medine Tarihi, İstanbul 2007. , “Zemzem”, TDVİA, XLIV, İstanbul, 2013.

Mekkî, Muhammed el Emin, Hulefâ-i İzâm-i Osmaniyye Hazretlerinin Haremeyn-i Şerifeyn'deki Asâr-i Mebrûre ve Meşkûre-i Hümayûnları, Dersaadet, 1318.

Radushev, Evgeni, v.d., Inventory of Ottoman Documents About Waqf Preserved in the Oriental Department at the St Cryril and Methodius National Library, part I, Sofia, 2003.

Sertoğlu, Midhat, “II. Murad'ın Vasiyetnamesi” Vakıflar Dergisi, VIII, Ankara, 1961.

Seyyid Muhammed, "Deşişe" TDVİA, IX, 1994.

Sönmez, Zeki, Mimar Sinan Dönemi Türk Mimarlı̆̆ ve Sanatı, Mimar Sinan 'ın Mekke ve Medine'deki Eserleri, İstanbul, 1988.

Tekindağ, Şehabeddin, "Fatih Devrinde Osmanlı Memlüklü Münasebetleri”, İstanbul Üniversitesi Edebiyat Fakültesi Tarih Dergisi, sayı 30, 1976.

Uzunçarşı11, İsmail Hakk1, "Sultan İkinci Murad'ın Vasiyetnâmesi” Vakıflar Dergisi, VI, 1958. , Mekke-i Mükerreme Emirleri, Ankara, 1984.

Yavuz, Hulusi, "Osmanlı Padişahlarının İftihar Ettikleri Unvanlardan Biri: Hadimü’l-Haremeyn”, Makalat, 1992/2. 
